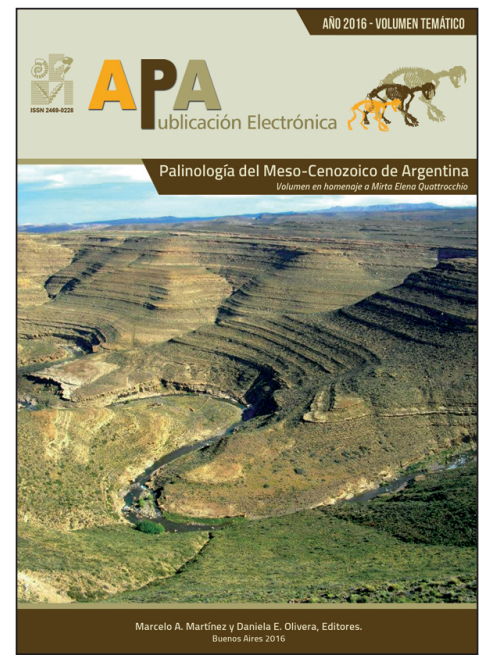

\title{
EARLY CRETACEOUS DINOFLAGELLATE CYSTS FROM THE NEUQUÉN AND AUSTRAL BASINS: A REVIEWAPPROACH
}

M. VERONICA GULER ${ }^{1}$

MELISA A. PAOLILLO'

PAULA A. MARTZ²

${ }^{1}$ Instituto Geológico del Sur - CONICET, Departamento de Geología, Universidad Nacional del Sur, San Juan 670,8000 Bahía Blanca, Argentina.

${ }^{2}$ Agencia Nacional de Promoción Científica y Tecnológica (ANPCyT), Facultad de Ciencias Exactas y Naturales, Universidad de Buenos Aires, Argentina.

Recibido: 3 de mayo de 2016 - Aceptado: 18 de octubre de 2016

Para citar este artículo: M. Veronica Guler, Melisa A. Paolillo, and Paula A. Martz (2016). Early Cretaceous dinoflagellate cysts from the Neuquén and Austral Basins: a review. En: M. Martínez y D. Olivera (Eds.), Palinología del Meso-Cenozoico de Argentina - Volumen en homenaje a Mirta Elena Quattrocchio. Publicación Electrónica de la Asociación Paleontológica Argentina 16 (2): 88-105.

Link a este artículo: http://dx.doi.org/10.5710/PEAPA.18.10.2016.116

DESPLAZARSE HACIA ABAJO PARA ACCEDER AL ARTíCULO

Asociación Paleontológica Argentina Maipú $6451^{\circ}$ piso, C1006ACG, Buenos Aires República Argentina Tel/Fax (54-11) 4326-7563 Web: www.apaleontologica.org.ar

Otros artículos en Publicación Electrónica de la APA 16(2):

\section{Prieto}

ANÁLISIS E INTERPRETACIÓN DE REGISTROS PALINOLÓGICOS DE SUCESIONES ALUVIALES DE LA REGIÓN PAMPEANA: REVISIÓN E IMPLICANCIAS PARA LA RECONSTRUCCIÓN DE LA VEGETACIÓN Y EL CLIMA DURANTE EL PLEISTOCENO TARDIO - HOLOCENO

\section{Borel, Guler, Navarro \& Astini}

ANCIENT COASTAL ENVIRONMENTS IN A MAASTRICHTIAN - ?PALEOCENE ATLANTIC SHORELINE: A PHYTOPLANKTON APPROACH

\section{Candel \& Borromei}

REVIEW OF THE PALAEOENVIRONMENTAL RECONSTRUCTION OF LATE QUATERNARY MARINE SEQUENCES, TIERRA DEL FUEGO (ARGENTINA) 


\title{
EARLY CRETACEOUS DINOFLAGELLATE CYSTS FROM THE NEUQUÉN AND AUSTRAL BASINS: A REVIEW
}

\author{
M. VERONICA GULER', MELISA A. PAOLILLO1, AND PAULA A. MARTZ²
}

\begin{abstract}
1Instituto Geológico del Sur - CONICET, Departamento de Geología, Universidad Nacional del Sur, San Juan 670, 8000 Bahía Blanca, Argentina. vguler@criba.edu.ar; mpaolillo@ingeosur-conicet.gob.ar

${ }^{2}$ Agencia Nacional de Promoción Científica y Tecnológica (ANPCyT), Facultad de Ciencias Exactas y Naturales, Universidad de Buenos Aires, Argentina. martzpaula@gmail.com
\end{abstract}

\begin{abstract}
The present work documents and gathers the most relevant records of the organic-walled dinoflagellate cysts from different sites of the Neuquén and Austral Basins. Most of these records have contributed to the palaeoenvironmental, biostratigraphical and palaeobiogeographical interpretations of the different stratigraphical units in both basins. The dinoflagellate cysts assemblages come from the Springhill, Upper Río Mayer, Piedra Clavada, Kachaike and "Margas Verdes" Formation of the Austral Basin, and from the upper part of the Vaca Muerta and the Agrio Formations of the Neuquén Basin, several of these stratigraphical units conform the main petroleum systems in both basins.

Key words. Cretaceous. Marine palynomorphs. Sedimentary basins. Argentina.

Resumen. QUISTES DE DINOFLAGELADOS DEL CRETÁCICO TEMPRANO DE LAS CUENCAS NEUQUINA Y AUSTRAL: UNA REVISIÓN. Se documentaron y recopilaron los registros más relevantes de los quistes de dinoflagelados de pared orgánica provenientes del Cretácico Inferior de las cuencas Neuquina y Austral en diferentes localidades de estudio. La mayoría de estos registros han contribuido a las interpretaciones paleoambientales, bioestratigráficas y paleobiogeográficas de diferentes sucesiones sedimentarias marinas en ambas cuencas. Las asociaciones de quistes de dinoflagelados provienen de las Formaciones Springhill, Río Mayer Superior, Piedra Clavada, Kachaike y "Margas Verdes" de la Cuenca Austral, y de la parte superior de las Formaciones Vaca Muerta y Agrio de la Cuenca Neuquina, varias de estas unidades estratigráficas conforman los principales sistemas petroleros de ambas cuencas.
\end{abstract}

Palabras clave. Cretácico. Palinomorfos marinos. Cuencas sedimentarias. Argentina.

ORGANIC-WALLED marine dinoflagellate cysts have offered valuable bioestratigraphic information for the Lower Cretaceous Basins from the Boreal (e.g., Prössl, 1990; Williams et al., 1990; Harding, 1990; Nør-Hansen, 1993) and Mediterranean Realms (e.g., Leereveld, 1997a,b; Torricelli, 2000), as well as in the Southern Hemisphere in Australia (Helby et al., 1987; Oosting et al., 2006) and Antartica (Riding and Crame 2002). In southernmost South America, dinoflagellate cysts have contributed to elucidate biostratigraphic and palaeobiogeographic aspects in the Austral Basin (e.g., Palamarczuk et al., 2000a,b; Guler et al., 2003; Guler and Archangelsky, 2006) and the Neuquén Basin (e.g., Peralta, 1997; Volkheimer, 2010; Guler et al., 2013), the two most important oil-producing basins from Argentina and Chile.

The Austral Basin is limited by the Southern Patagonian Andes to the west and by the Deseado Massif to the east
(Biddle et al., 1986; Robbiano et al., 1996). It includes about 8000-m-thick deposits ranging from the Late Jurassic to the Cenozoic (e.g., Schwarz et al., 2011). During the Early Cretaceous, a regionally extended succession, mostly composed of marine fine sediments, was deposited in a sagging phase (Biddle et al., 1986; Robbiano et al., 1996). The Springhill Formation and its equivalents (lower Río Mayer and the subsurface "Lower Inoceramus" Formations) represent the oldest sedimentary rocks of the Austral Basin, which were deposited mostly during Berriasian-Barremian times. They represent a long-term (>25 My) transgressive cycle likely controlled by low-frequency sea-level fluctuations in a back arc setting (e.g., Biddle et al., 1986; Robbiano et al., 1996; Arbe and Fernández Bell Fano, 2002), commonly developed as the infill of extensive topographic depressions (Schwartz et al., 2011). The Aptian to Albian upper part of the Río Mayer 
Formation, the equivalent Kachaike Formation and the subsurface deep marine "Margas Verdes" unit, were accumulated at the end of this thermal subsidence phase.

The Neuquén Basin is located in central-western Argentina between $32^{\circ}-40^{\circ}$ South Latitudes and covers part of the Mendoza, Neuquén, Río Negro and La Pampa provinces. The infill of the Basin comprises more than $7000 \mathrm{~m}$ of marine and continental sedimentary rocks, ranging in age from the Late Triassic to the Paleocene (Legarreta and Gulisano, 1989; Legarreta and Uliana, 1991). It is a major Mesozoic to Neogene depocenter, and one of the few Southern Hemisphere basins having an excellent marine record from latest Jurassic to mid Early Cretaceous (early Barremian) times. During that interval, the area formed a back-arc basin linked to the Pacific Ocean on its western margin through a volcanic island arc (Legarreta and Uliana, 1991). It is limited by cratonic areas to the northeast (Sierra Pintada System) and southeast (North Patagonian Massif). During the Early Cretaceous, the basin formed large marine embayments linked to episodes of relative sea level rise (Legarreta and Gulisano, 1989). The marine sedimentary rocks accumulated during the Early Cretaceous (Berriasian-early Barremian) are represented by the Vaca Muerta and Agrio formations of the Mendoza Group (Groeber, 1946). The thick and laterally continuous exposures, and the abundant fossil record of these deposits, make the Neuquén Basin an excellent site for stratigraphic, palaeontological and geochemical studies.

The aim of this work is to review and summarize the most relevant biostratigraphical and palaeobiogeographical
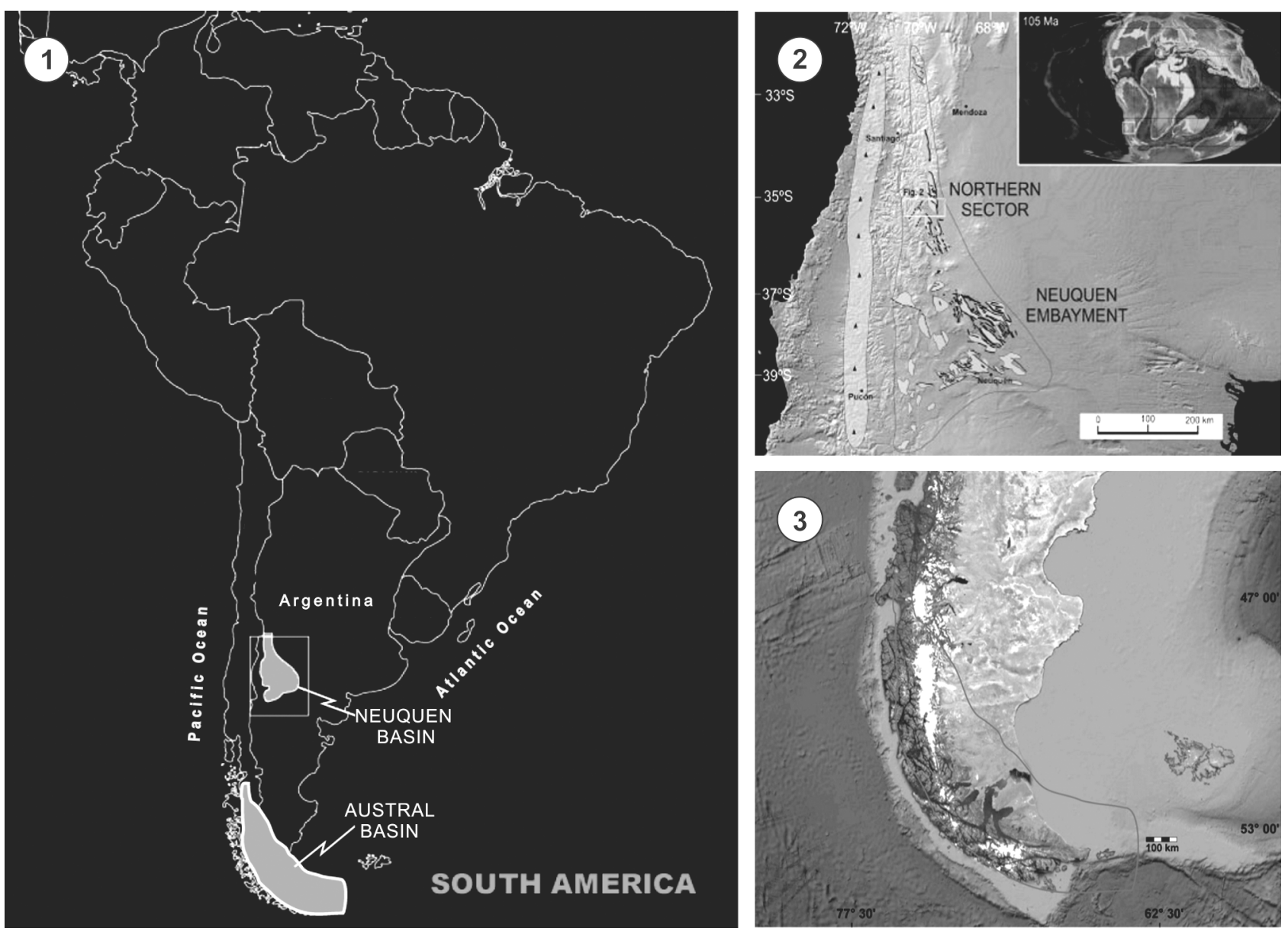

Figure 1. 1, Location map of the Neuquén and Austral Basins in the southernmost part of South America. 2, Location of the Neuquén Basin in the central-west Argentina. 3, Location of the Austral Basin in the southern tip of Argentina. 
data based on dinoflagellate cysts published to date from Early Cretaceous sedimentary succesions of the Austral and Neuquén basins. Most of the stratigraphical units herein presented include several economically-important hydrocarbon source and reservoir rocks (Uliana and Legarreta, 1993).

\section{SIGNIFICANT EARLY CRETACEOUS DINOFLAGELLATE CYSTS RECORD FROM THE SOUTHERNMOST PART OF SOUTH AMERICA \\ Neuquén Basin}

Palynological studies on Cretaceous deposits of the Neuquén Basin, focused on dinoflagellate cysts, began in the 80 's. The oldest records come from the black shales of the Vaca Muerta Formation of early Tithonian-early Valanginian age (Legarreta and Uliana, 1991; Legarreta et al., 1993). Quattrocchio and Volkheimer (1985) documented late Berriasian dinoflagellate cysts in the Mallin Quemado locality, Neuquén province. These authors recognized 12 dinoflagellate cyst taxa including Gonyaulacysta sp. A, cf. Rhaetogonyaulax sp., Pareodinia cf. P. ceratophora Deflandre 1947 emend. Gocht 1970, Acanthaulax sp., Leptodinium ambiguum (Deflandre 1939) Helenes 1984, Ctenidodinium tenellum Deflandre 1939, Hystrichosphaerina neuquina Quattrocchio and Volkheimer 1983 emend. Quattrocchio and Sarjeant 1992, Systematophora sp. A, Prolixosphaeridium sp., Sentusidinium sp. A, Lithodinia sp. A., and the new species Cribroperidinium reticulatum Quattrocchio and Volkheimer 1985. Afterwards, Quattrocchio and Volkheimer (1990) added Pareodinia ceratophora var. pachyceras (Sarjeant 1959) Lentin and Williams 1973, Sentusidinium villersense (Sarjeant 1968) Sarjeant and Stover 1978, and Systematophora penicillata (Ehrenberg 1843) Sarjeant 1980 to the previous taxonomic list of the Mallín Quemado locality, and considered Hystrichosphaerina neuquina and Cribroperidinium reticulatum as endemic species of the Neuquén Basin.

Dinoflagellate cyst assemblages from the late Valanginian-early Hauterivian Pilmatué Member of the Agrio Formation were documented for the first time by Quattrocchio and Volkheimer (1990) at the Pichaihue Abajo, Bajada Vieja and Cerro Mesa localities. More detailed studies of the Pilmatué Member were carried out by Peralta (1997) at the Cerro Mesa and Cerro Negro of Covunco sections (Neuquén province) where they recorded about 42 taxa. With the exception of the gymnodinialean genus Dinogymnium Evitt et al. 1967 emend. Lentin and Vozzhennikova 1990, the species identified belong to the Order Gonyaulacales, chorate and proximochorate cysts (e.g., Achomosphaera neptuni (Eisenack 1958) Davey and Williams 1966a, A. ramulifera (Deflandre 1937) Evitt 1963, Kleithriasphaeridium fasciatum (Davey and Williams 1966b) Davey 1974, K. simpliscispinum (Davey and Williams 1966b) Davey 1974, Oligosphaeridium complex (White 1842) Davey and Williams 1966b, Spiniferities ramosus (Ehrenberg 1838) Mantell 1854, Surculosphaeridium longifurcatum (Firtion 1952) Davey et al. 1966, Systematophora rosenfeldii Volkheimer and Sarjeant 1993, Tanyosphaeridum variecalamum (Davey and Williams 1966b); proximate cysts (e.g., Batiacasphaera asperata Backhouse 1987, Cassiculosphaeridia magna Davey 1974 emend. Harding 1990, Cribroperidinium orthoceras (Eisenack 1958) Davey 1969 emend. Sarjeant 1985, C. muderongense (Cookson and Eisenack 1958) Davey 1969, among the most frequent) and cavate cysts with the common presence of Dingodinium cerviculum Cookson and Eisenack 1958 emend. KhowajaAteequzzaman et al. 1990 (Peralta, 1997). The relative abundance data of these three morphological groups of cysts contributed to characterize the marine palaeoenvironments which oscillates from external neritic to neritic and coastal environments through the section (Peralta and Volkheimer 1997, 2000). In 2010, Volkheimer described a late Valanginian-early Hauterivian dinoflagellate cyst assemblage from Santa Elena locality, and recognized 30 morphotypes with the definition of two new endemic species for the Member: Oligosphaeridium quattrocchiae Volkheimer 2010 and Muderongia sarjeantii Volkheimer 2010. Recently, Paolillo et al. (2015) identified at the Bajada del Agrio locality, 41 species belonging to the Order Gonyaulacales. Assemblages are dominated by Cribroperidinium spp., Hystrichodinium pulchrum Deflandre 1935, Circulodinium distinctum (Deflandre and Cookson 1955) Jansonius 1986 and Florentinia spp. Additionally, three biostratigraphically significant events were identified for the Lower Cretaceous of the Neuquén Basin, that consist of the oldest (first) and/or the youngest (last) occurrence of a particular species, herein referred as "First appearance datums" or FADs and "Last appearance datum" or LADs, respectively. These 


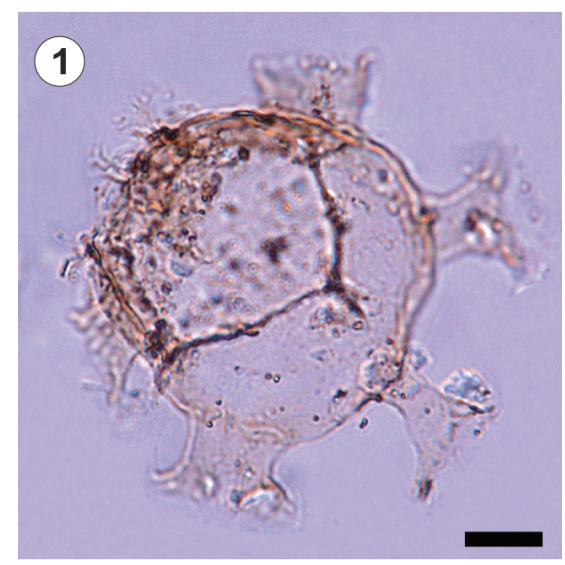

(2)
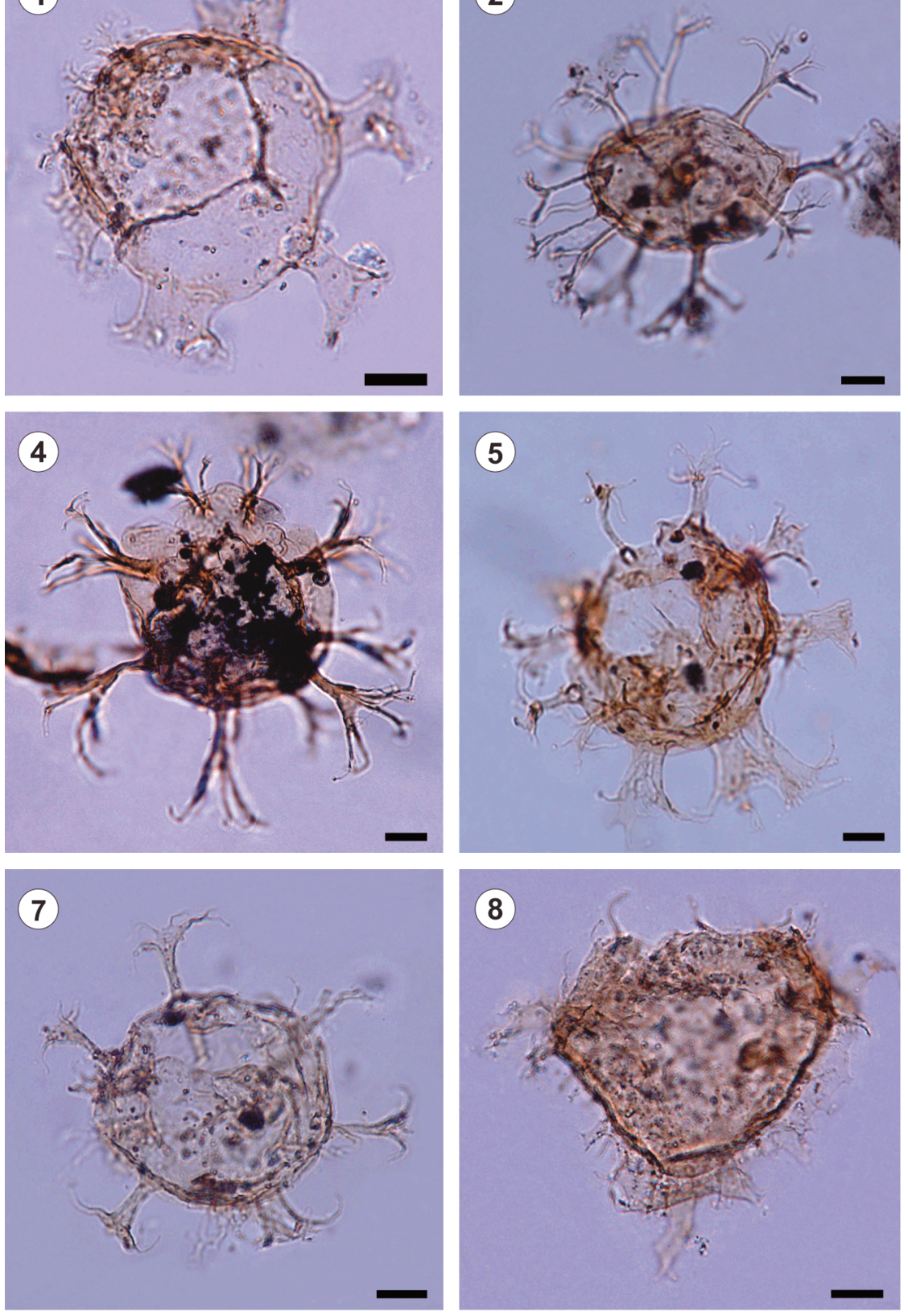

10

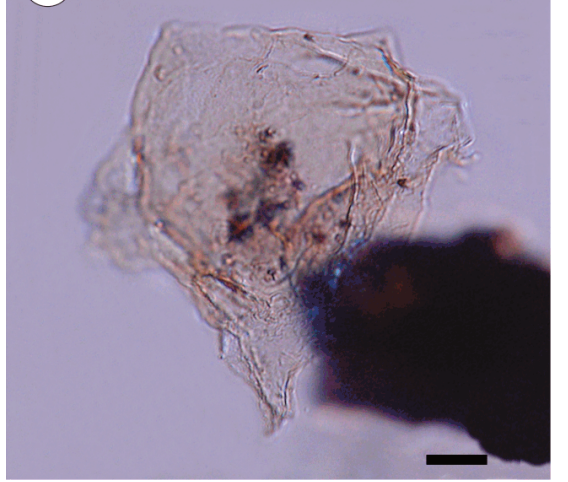

5
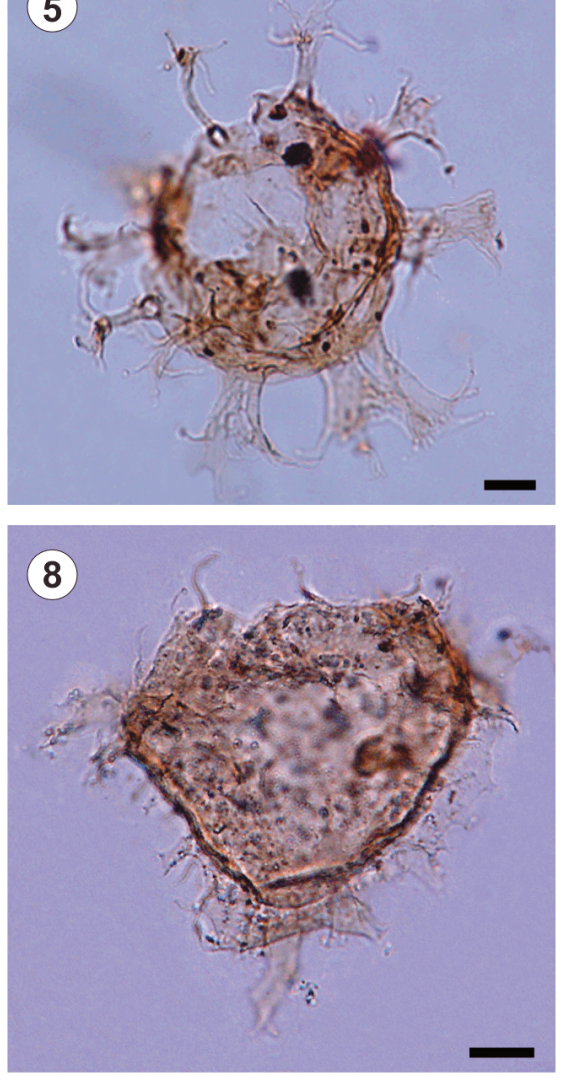

(11)

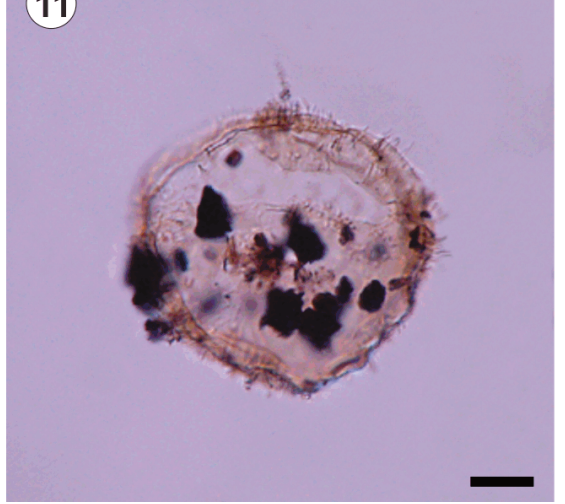

(3)

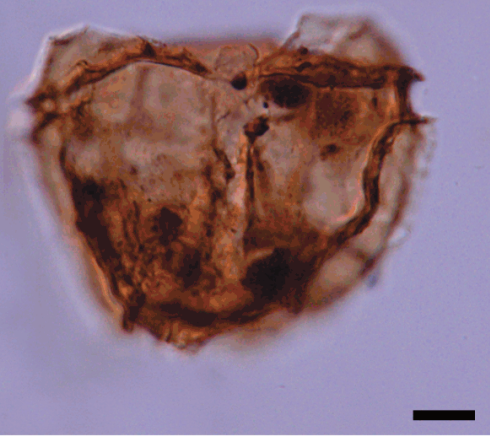

(6)

9

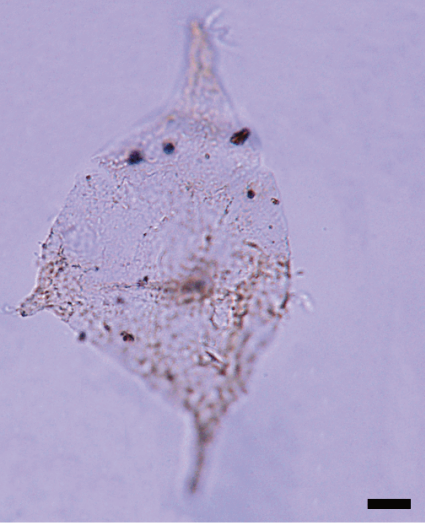

12

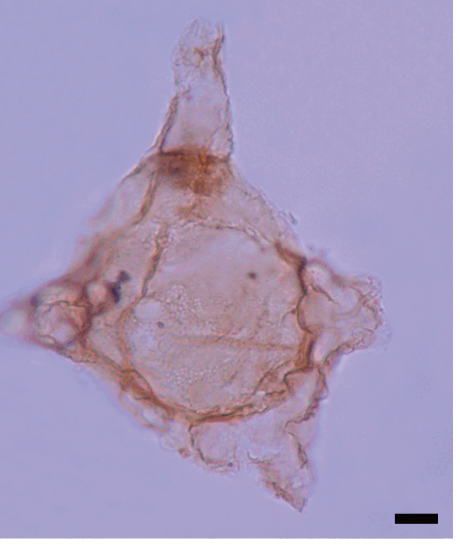


events are the FAD of Callaiosphaeridium asymmetricum (Deflandre and Courteville 1939) Davey and Williams 1966b emend. Clarke and Verdier 1967, the FAD and the LAD of Cymososphaeridium validum Davey 1982. The FAD of CaIlaiosphaeridium asymmetricum was recorded at the base of the Holcoptychites neuquensis Subzone of the $H$. neuquensis Zone of Aguirre Urreta and Rawson (1997), assigned to the earliest Hauterivian. The FAD of Cymososphaeridium validum was identified at the uppermost part of the Hoplitocrioceras gentilii Subzone of the $H$. gentilii Zone of Aguirre Urreta and Rawson (1997), dated as late early Hauterivian, and the LAD of this species was recorded at the lower part of the Crioceratites diamantensis Zone of Aguirre Urreta and Rawson (1997), of a late Hauterivian age.

The first study on dinoflagellate cysts from the Agua de la Mula Member was carried out at the Agua de la Mula and Bajada del Agrio sections by Hernández et al. (2005) and Ottone et al. (2008). The gonyaulacalean Circulodinium distinctum, Cribroperidinium orthoceras, Cribroperidinium spp., Exochosphaeridium bifidum (Clarke and Verdier 1967) Clarke et al. 1968, Florentinia mantellii (Davey and Williams 1966b) Davey and Verdier 1973, Florentinia spp., Kiokansium unituberculatum (Tasch in Tasch et al. 1964) Stover and Evitt 1978, Hystrichodinium pulchrum and Oligosphaeridium complex are the dominant taxa in these assemblages and particularly, ceratiacean morphotypes such as Phoberocysta neocomica (Gocht 1957) Millioud 1969 emend. Helby 1987, Muderongia staurota Sarjeant 1966 emend. Monteil 1991b, M. pariata Duxbury 1983 emend. Monteil 1991b and other closely related forms are well represented. Besides the presence of the endemic Oligosphaeridium quattrocchioae, most of the species recovered are cosmopolitan such as
Circulodinium distinctum, Cribroperidinium spp., Exochosphaeridium spp., Kiokansium unituberculatum, Dingodinium cerviculum and Oligosphaeridium complex, which are present in almost all the assemblages throughout the Agua de la Mula Member. Ceratiacean cysts are represented by Phoberocysta neocomica, Pseudoceratium pelliferum Gocht 1957 emend. Dörhöfer and Davies 1980 and several morphotypes of the genus Muderongia Cookson and Eisenack 1958, mainly M. cf. M. staurota, M. pariata, M tomaszowensis Alberti 1961 emend. Riding et al. 2001, M. cf. M. siciliana Torricelli 1997, and $M$. tetracantha (Gocht 1957) Alberti 1961 emend. Monteil 1991b (Hernández et al., 2005; Ottone et al., 2008; Guler et al., 2013; Paolillo, personal observation). Ottone and Pérez Loinaze (2002) erected a new species Muderongia brachialis from the Agua de la Mula Member at Paraje El Rincón (Río Agrio). It is a biostratigraphycally useful taxon within the Neuquén Basin, since its occurrence is restricted to the Spitidiscus ricardii and Crioceratites schlagintweiti ammonite Zones, which spans the latest early Hauterivian to the base of the late Hauterivian.

Table 1 contains the dinoflagellate cyst species identified in the Neuquén Basin and referenced according to the Fensome and Williams Index; Fensome and Williams (2004).

\section{Austral Basin}

Early Cretaceous dinoflagellate cyst assemblages recorded in the marine deposits of the Austral Basin, mainly come from the offshore subsurface sequences, whereas studies in continental areas of Patagonia are scarce. Based on dinoflagellate cysts and ammonites, Pöthe de Baldis and Ramos (1983, 1988) analized Aptian dinoflagellate cysts from the west of Santa Cruz Province, and Ottone and

Figure 2. Early Cretaceous dinoflagellate cysts from the Pilmatué and Agua de la Mula Members of the Agrio Formation, Neuquén Basin. 1, Callaiosphaeridium asymmetricum (Deflandre and Courteville) Davey and Williams emend. Clarke and Verdier, apical view, low focus BA 4218 35/118,5. 2, Cymososphaeridium validum Davey, lateral view, intermediate focus BA 4229 46,5/100. 3, Meiourogonyaulax stoveri Millioud, ventral view, high focus BA AG3d 50/103. 4, Surculosphaeridium longifurcatum (Firtion) Davey et al., dorsal view, low focus BA 4229 37,5/109. 5, Oligosphaeridium quattrocchioae Volkheimer, apical view, high focus BA AG3d 29/108,5. 6, Dingodinium cerviculum Cookson and Eisenack emend. Mehrota and Sarjeant, general view BA AG5b 51/104. 7, Oligosphaeridium complex (White) Davey and Williams, oblique apical view, low focus BA 4227 47/108,5. 8, Phoberocysta neocomica (Gocht) Helby, dorsal view, low focus BA 4227 54/116,5. 9, Pseudoceratium pelliferum Gocht emend. Dörhöfer and Davies, ventral view, cross section BA 4211 19/110,5. 10, Muderongia pariata Duxbury emend. Monteil, dorsal view, low focus BA AG10b 35/120. 11, Nexosispinum sp. dorsal view, high focus BA AG21a 37,5/117. 12, Muderongia cf. M. tomaszowensis Alberti emend. Monteil, ventral view high focus BA 4227 20,5/121,5. Scale bar=10 $\mu \mathrm{m}$. 
TABLE 1 - List of the dinoflagellate cyst taxa identified from the Early Cretaceous assemblages of the Neuquén and Austral Basins.

Taxa Neuquén Basin Austral Basin

Acanthaulax sp.

$X$

Achomosphaera neptuni (Eisenack 1958) Davey and Williams $1966 a$

A. ramulifera (Deflandre 1937) Evitt 1963

Batiacasphaera asperata Backhouse 1987

Callaiosphaeridium asymmetricum (Deflandre and Courteville 1939)

Davey and Williams 1966 b emend. Clarke and Verdier 1967

Canninginopsis denticulata Cookson and Eisenack 1962

Cassiculosphaeridia magna Davey 1974 emend. Harding 1990

Chichaouadinium boydii (Morgan 1975) Bujak and Davies 1983

Circulodinium distinctum (Deflandre and Cookson 1955) Jansonius 1986

Cometodinium cf. C. comatum Srivastava 1984 emend. Monteil 1991a

Cribroperidinium confossum (Duxbury 1977) Helenes 1984

C. muderongense (Cookson and Eisenack 1958) Davey 1969

C. orthoceras (Eisenack 1958) Davey 1969 emend. Sarjeant 1985

C. reticulatum Quattrocchio and Volkheimer 1985

Ctenidodinium tenellum Deflandre 1939

Cyclonephelium vannophorum Davey 1969

Cymososphaeridium validum Davey 1982

Dingodinium cerviculum Cookson and Eisenack 1958 emend.

Kowaja-Ateequzzaman et al. 1990

Dinogymnium Evitt et al. 1967 emend. Lentin and Vozzhennikova 1990

Dinopterygium tuberculatum (Eisenack and Cookson 1960) Stover and Evitt 1978

Exochosphaeridium bifidum (Clarke and Verdier 1967) Clarke et al. 1968

Florentinia mantellii (Davey and Williams 1966b) Davey and Verdier 1973

Gonyaulacysta sp. A.

Hapsocysta peridictya (Eisenack and Cookson 1960) Davey 1979 emend. Davey 1979

Herendeenia postprojecta Stover and Helby 1987

Hystrichodinium pulchrum Deflandre 1935

Hystrichosphaerina neuquina Quattrocchio and Volkheimer 1983 emend.

Quattrocchio and Sarjeant 1992

Kaiwaradinium scrutillinum Backhouse 1987

Kiokansium unituberculatum (Tasch in Tasch et al. 1964) Stover and Evitt 1978

Kleithriasphaeridium fasciatum (Davey and Williams 1966b) Davey 1974

K. simpliscispinum (Davey and Williams 1966b) Davey 1974

Leptodinium ambiguum (Deflandre 1939) Helenes 1984 (as Millioudodinium ambiguum)
$X$

\section{x}

$x$

x

x

$\begin{array}{ll}x & x \\ & x \\ x & x \\ & x \\ x & x \\ x & \\ x & \end{array}$

$x$

$x$

$x$ $x$ $x$ $x$ $x$ $x$ $x$

\begin{tabular}{l}
$x$ \\
$x$ \\
$x$ \\
$x$ \\
\hline
\end{tabular}


TABLE 1 - Continuation.

Taxa

Lithodinia $s p . A$

Litosphaeridium arundum (Eisenack and Cookson 1960) Davey 1979 emend. Lucas-Clark 1984

Muderongia brachialis Ottone and Pérez Loinaze 2002

M. pariata Duxbury 1983 emend. Monteil 1991b

$x$

M. sarjeantii Volkheimer 2010

M. staurota Sarjeant 1966 emend. Monteil 1991b

M. cf. M. staurota Sarjeant 1966 emend. Monteil $1991 b$

M. tetracantha (Gocht 1957) Alberti 1961 emend. Monteil 1991 b

M. tomaszowensis Alberti 1961 emend. Riding et al. 2001

M. cf. M. siciliana Torricelli 1997

Nematosphaeropsis densiradiata (Cookson and Eisenack 1962b) Stover and Evitt 1978

Odontochitina operculata (Wetzel 1933) Deflandre and Cookson 1955

Oligosphaeridium complex (White 1842) Davey and Williams $1966 b$

0. quattrocchiae Volkheimer 2010

O. pulcherrimum (Deflandre and Cookson 1955) Davey and Williams $1966 b$

Ovoidinium cinctum (Cookson and Eisenack 1958) Davey 1970

Pareodinia cf. P.ceratophora Deflandre 1947 emend. Gotch 1970

Pareodinia ceratophora var. pachyceras (Sarjeant 1959) Lentin and Williams 1973

Phoberocysta neocomica (Gocht 1957) Millioud 1969 emend. Helby 1987

Prolixosphaeridum conulum Davey 1969

P. parvispinum (Deflandre 1937) Daveyet al. 1969

Prolixosphaeridium $s p$.

Pseudoceratium pelliferum Gocht 1957 emend. Dörhöfer and Davies 1980

Senoniasphaera tabulata Helby 1987

$x$

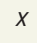

$x$

$x$

\begin{tabular}{|c|c|}
\hline & $x$ \\
\hline & $x$ \\
\hline$x$ & \\
\hline$x$ & \\
\hline$x$ & $x$ \\
\hline & $x$ \\
\hline & $x$ \\
\hline$x$ & \\
\hline$x$ & \\
\hline & $x$ \\
\hline$x$ & \\
\hline$x$ & \\
\hline$x$ & \\
\hline$x$ & \\
\hline$x$ & \\
\hline$x$ & \\
\hline$x$ & \\
\hline$x$ & \\
\hline
\end{tabular}

Tanyosphaeridum variecalamum (Davey and Williams 1966b)

References correspond to the Fensome and Williams Index; Fensome and Williams (2004). 

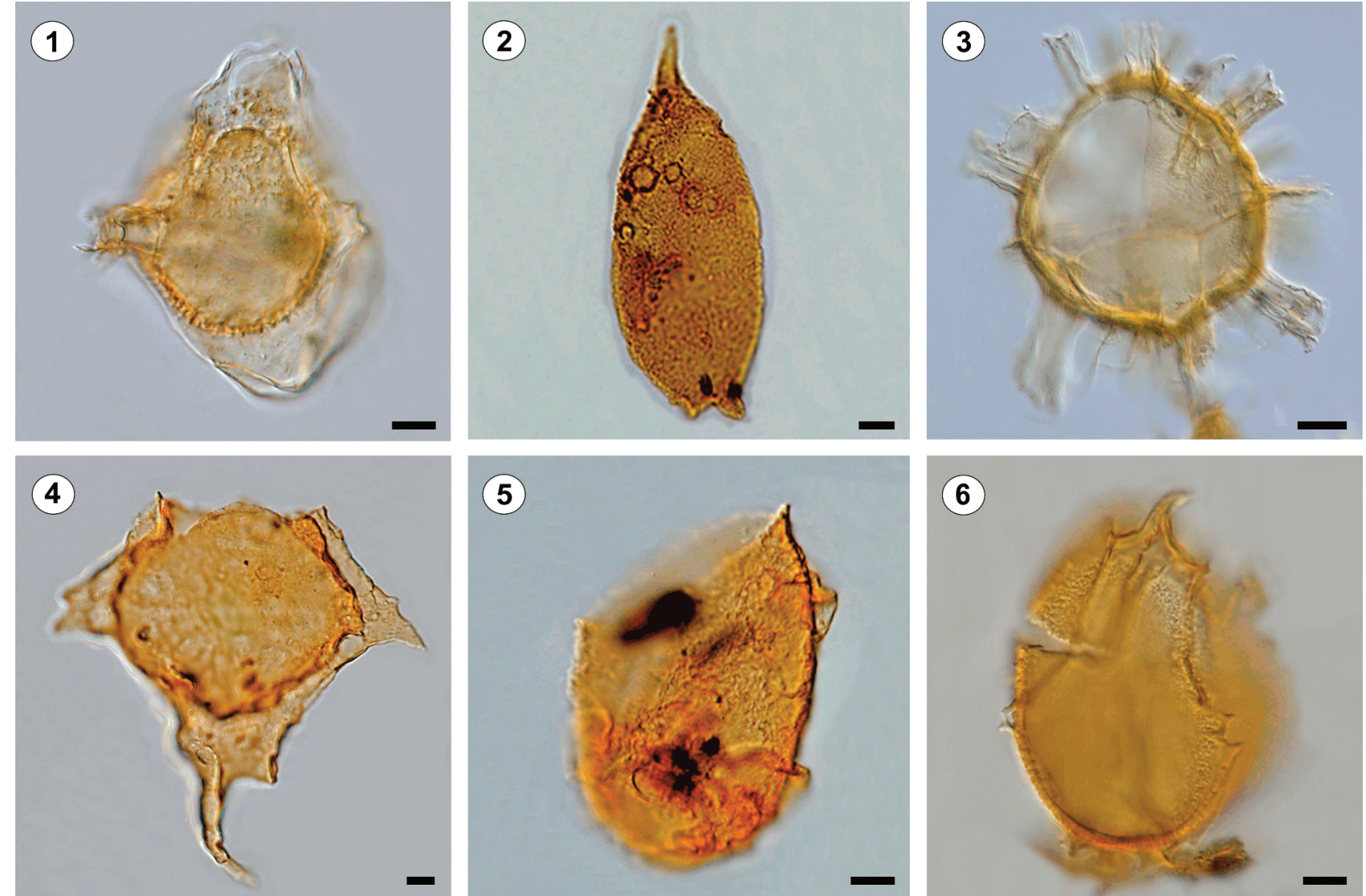

(5)
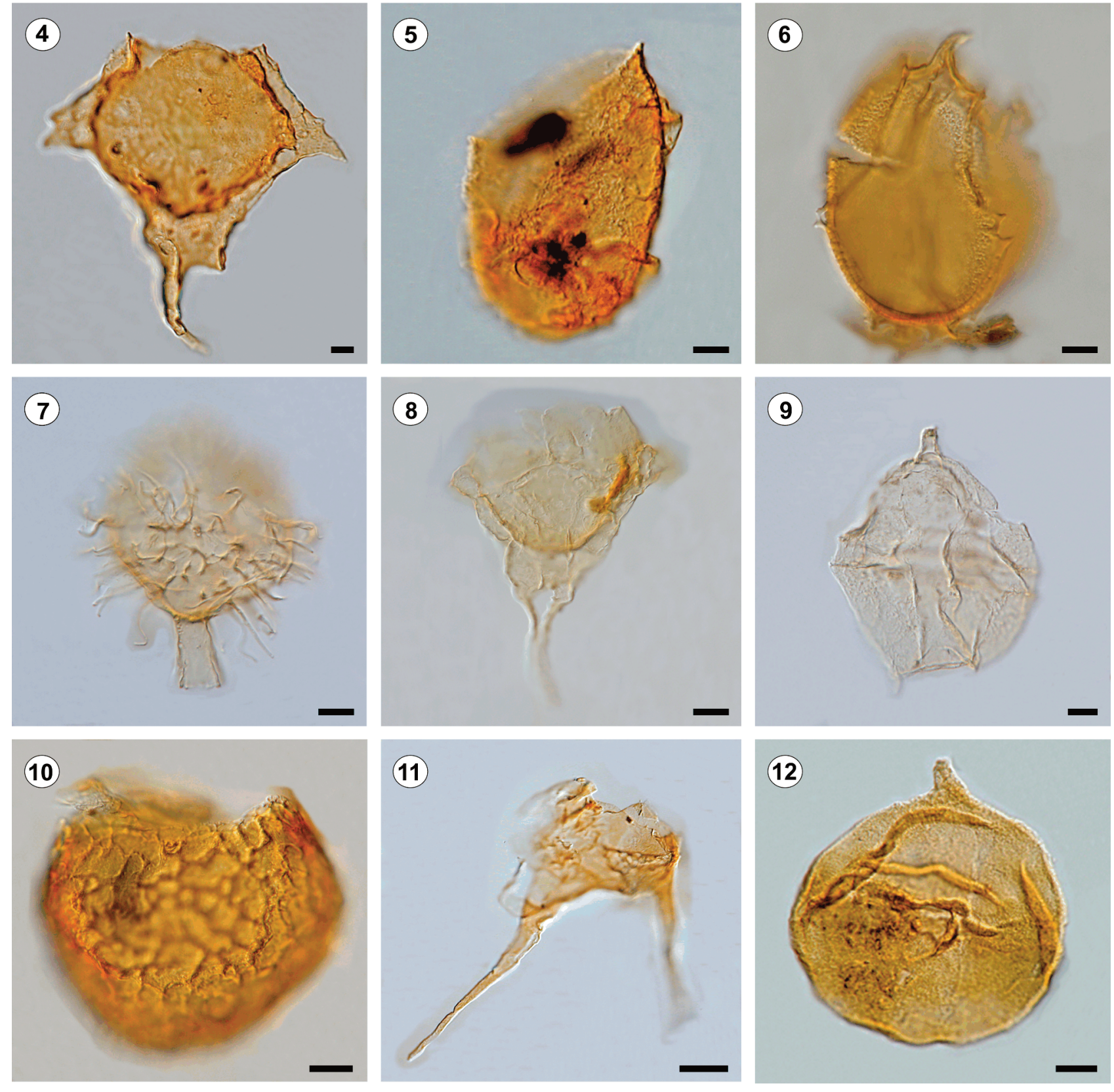
Aguirre Urreta (2000) suggested a probable late early Hauterivian-early Barremian age for the Springhill Formation, at southwestern Santa Cruz Province. Cornú (1986) described the palynoflora from wells sections offshore eastern Tierra del Fuego province and indicates four informal dinoflagellate cyst zones for the upper marine interval of the Springhill and the Lower Inoceramus formations. Also, Palamarczuk et al. $(2000 a, b)$ recognized a late ValanginianHauterivian lower marine interval in well sections offshore eastern Santa Cruz.

Offshore northeastern Tierra del Fuego province, Quattrocchio et al. (2006) correlated deposits of the Springhill Formation with the Interulobites-Foraminisporis Assemblage Zone (upper Valanginian-upper Hauterivian) of Archangelsky et al. (1984), defined for the Austral Patagonia, and with the upper Valanginian-lower Aptian Cyclusphaera psilataClassopollis Zone of Volkheimer (1980), for the Neuquén Basin. They recorded a dinoflagellate cyst-dominated palynomorph assemblage composed by Circulodinium distinctum, Cometodinium cf. C. comatum Srivastava 1984 emend. Monteil 1991a, Cribroperidinium confossum (Duxbury 1977) Helenes 1984, Cyclonephelium vannophorum Davey 1969 and Oligosphaeridium complex, suggesting transitional to offshore marine conditions, and other assemblage characterized by Aptea spp. and prasinophyceaen algae (Tasmanites Newton 1875 and Pterospermella Eisenack 1972) indicating brackishwater environments.

Well preserved and moderately diverse dinoflagellate cyst assemblages were recovered from the Springhill Formation in eight wells located offshore southeastern Argentina (Guler et al., 2003; Guler et al., 2015). A sequence of eight age-diagnostic bioevents characterizes the easternmost Early Cretaceous deposits of the Austral Basin. These are, in ascending order: the LAD of Senoniasphaera tabulata Helby 1987, the LAD of Kleithriasphaeridium fasciatum, the FAD of Prolixosphaeridium parvispinum (Deflandre 1937) Davey et al. 1969, the LAD of Phoberocysta neocomica, the FAD of Herendeenia postprojecta Stover and Helby 1987, the FAD of Odontochitina operculata (Wetzel 1933) Deflandre and Cookson 1955, the LAD of Cassiculosphaeridia magna and the LAD of Kaiwaradinium scrutillinum Backhouse 1987. These bioevents constrain the age of the subsurface sections to the late Barremian. Furthermore, it was recognized the upper part of the Muderongia testudinaria and the $\mathrm{Mu}$ derongia australis Zones of Helby et al. (1987), extending both zones to the beginning of the late Barremian and the early Aptian (Oosting et al., 2006), respectively. Palaeopeoperidiniod cysts-dominated assemblages of cf. Ovoidinium sp. were recorded consistently at the top of most of the sequences (Guler et al., 2003, 2015), which presumable represent endemic taxa for the southeastern Atlantic Ocean. An acme of Ovoidinium cinctum (Cookson and Eisenack 1958) Davey 1970 mark the 0 . (as Ascodinium) cinctum Subzone (Helby et al., 1987, 2004) when it is present at the uppermost part of the M. australis Zone. Oosting et al. (2006) document the consistent presence of 0 . cinctum and recognize the Subzone in the M. australis and O. operculata Zones, boundary in the earliest Aptian. The late Barremian age proposed for the Springhill Formation is in accordance with the strong diachronism of the unit, being the youngest deposits at the east and north of the basin; the wells are located in front of the southernmost tip of Santa Cruz province, and these

Figure 3. Barremian dinoflagellate cysts from the Springhill Formation, offshore Austral Basin. 1, Dingodinium cerviculum Cookson and Eisenack, right lateral view, cross section, BA PB Pal 6301 100.5/44.5 EF J30/4. 2, Batioladinium micropodum (Eisenack and Cookson) Brideaux, ventral view, Iow focus, BA PB Pal 6306 39/106 EF W30. 3, Kleithriaspheridinium fasciatum (Davey et al.) Davey, oblique ventral view, low focus, BA Pb Pal 6312 24/113 EF M24/3. 4, Muderongia australis Helby, dorsal view/low focus, BA Pb Pal 6306 31/99 EFZ31/4. 5, Aprobolocysta sp. cf. A. alata Backhouse, left lateral view, intermediate, BA PB Pal 6307 29.5/105 EF V29/2. 6, Herendeenia postprojecta Stover and Helby, oblique ventral view, cross section, BA PB Pal 6301 23.5/112.5 EF N23. 7, Coronifera oceanica Cookson and Eisenack, ventral view, high focus, BA PB Pal 6301 33.5/113 EF N35/1. 8, Muderongia imparilis (Duxubury) Bint, dorsal view, high focus, BA PB Pal 6306 47/104 EF W47/4. 9, cf. Ovoidinium sp., dorsal view, intermediate focus, BA PB Pal 6301 48107.5 EF H48/2. 10, Cassiculosphaeridia magna Davey, dorsal view, intermediate focus, BA PB Pal 6312 46.5/117 EF H47/3. 11, Odontochitina operculata (Wetzel) Deflandre and Cookson, dorsal view, low focus, 6306 48.9/112 W27. 12, Apteodinium granulatum (Eisenack) Lucas-Clark BA Pb Pal ventral view, low focus, BA PB Pal 6306 43/104.5 EF V43/4. Scale bar= 10 $\mu \mathrm{m}$. 

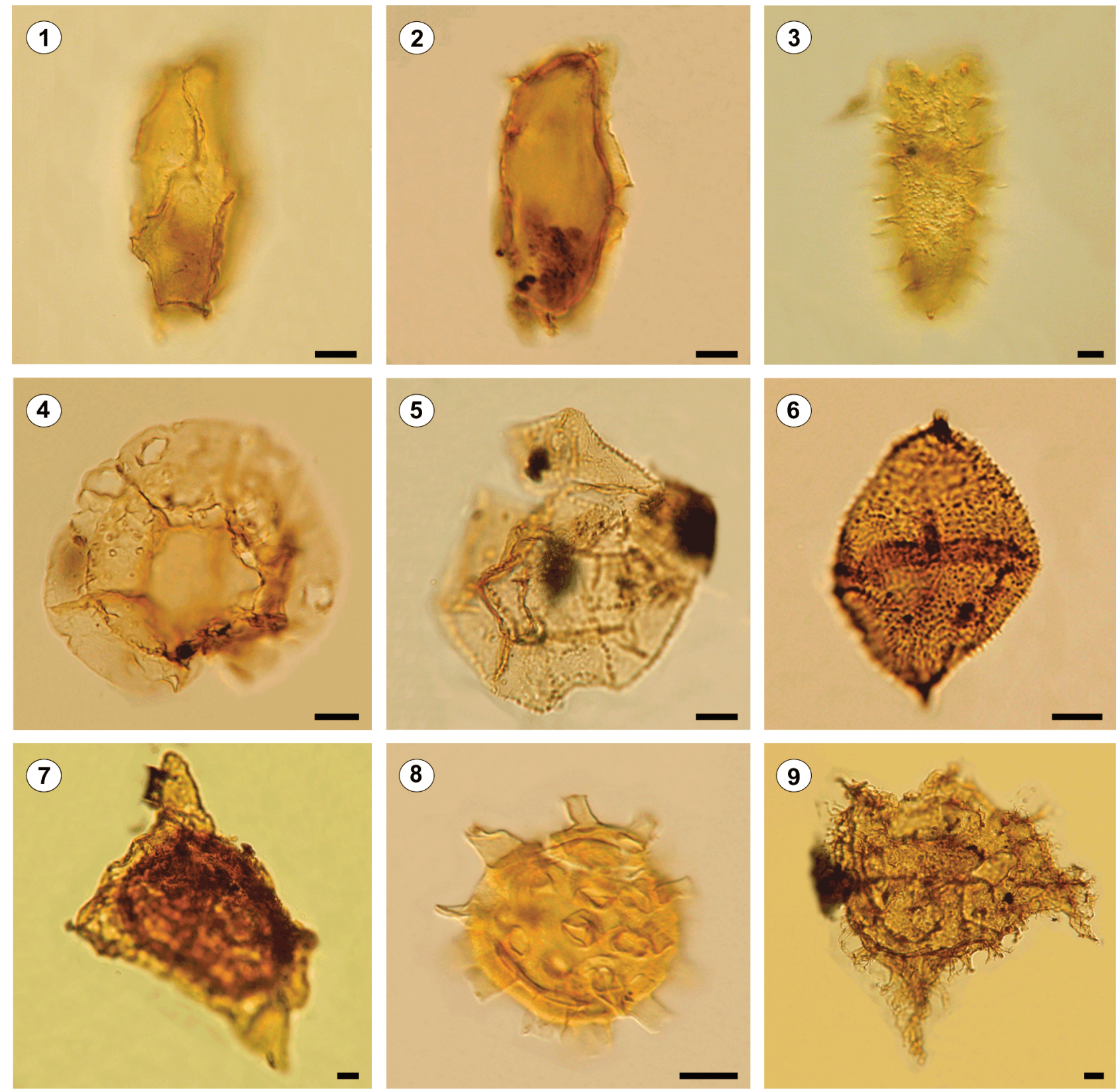

8
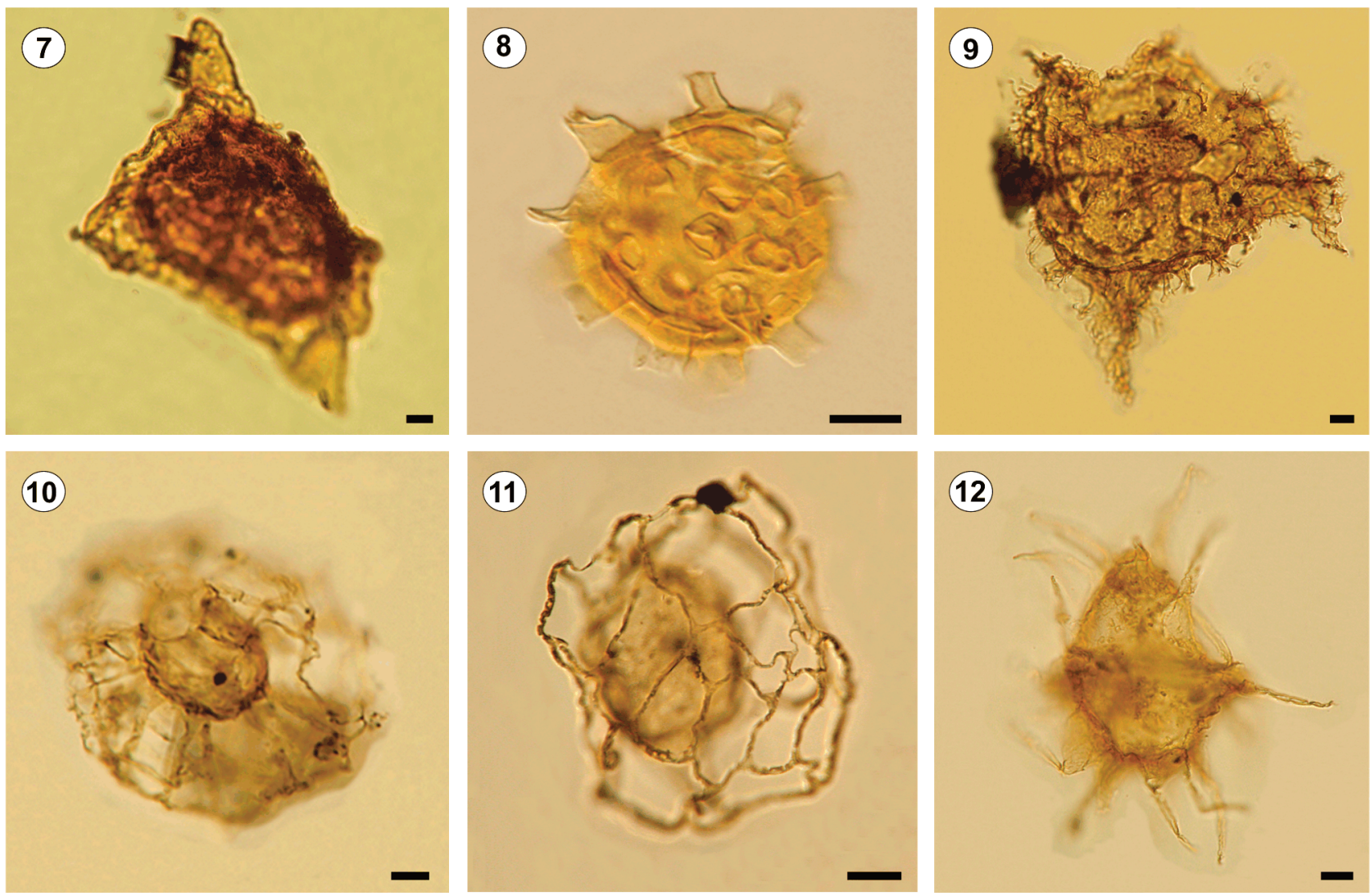
sequences accumulated in the eastern margin of the basin.

Late Aptian, Albian and early Cenomanian dinoflagellate cyst assemblages were recorded at the uppermost Río Mayer Formation and the overlying Kachaike or the equivalent Piedra Clavada Formations outcrop sections, as well as from the deep marine shales of the "Margas Verdes" Formation in the subsurface deposits. The Kachaike Formation is a typical Albian unit in the southwest of Patagonia at the San Martin lake area, and the uppermost part of the Río Mayer Formation is well-known by its rich fossiliferous content, where marine invertebrates include ammonoids of the Aptian/Albian transition. The FADs of Litosphaeridium arundum (Eisenack and Cookson 1960) Davey 1979 emend. Lucas-Clark 1984 (Fig. 2.2), Chichaouadinium boydii (Morgan 1975) Bujak and Davies 1983, Prolixosphaeridum conulum Davey 1969 and Dinopterygium tuberculatum (Eisenack and Cookson 1960) Stover and Evitt 1978 and the LAD of Muderongia tetracantha constitute key biostratigraphic events and constrain the age of the Kachaike Formation and the coetaneous Piedra Clavada Formation in different sites of southwestern Patagonia (Baldoni et al., 2001; Guler and Archangelsky, 2006; Medina et al., 2008). The underlying uppermost Río Mayer Formation is well-known by their rich fossiliferous content, it is a classical section in the Santa Cruz province where marine invertebrates include ammonoids of the Aptian/Albian transition, whereas the Piedra Clavada Formation is dated as early Albian based on ammonoids of the genus Beudanticeras (Medina et al., 2008). The presence of Dingodinium cerviculum in these deposits represents the LAD for the species in the Austral Basin, and it is associated with Aptian/Albian transition ammonite fauna; in accor- dance with the range of the species in Australia which extends into the lowest Muderongia tetracantha Zone. It was recognized in these Albian units the Subzone b of Endoceratium turneri Zone and the coeval Muderongia teracantha Interval Zone of Morgan (1980) and Helby (1987), of early Albian age; the LAD of Muderongia tetracantha marks the top of these zones. Subsurface sections of the "Margas Verdes" Formation from the offshore Austral Basin exhibit a complete Albian dinoflagellate cyst event sequences (Palamarczuk et al., 2000a; Guler, personal observation), mostly the last occurrences where the continuous and common occurrence of Hapsocysta peridictya (Eisenack and Cookson 1960) Davey 1979 emend. Davey 1979 is indicative of a minimum early Albian age. The $H$. peridictya stratigraphic range extends from the top of the Subzone $a$, to the top of the Subzone b of the Pseudoceratium turneri of Morgan (1980), assigned to the early Albian. In Australia, the last occurrences of $H$. peridictya and $M$. tetracantha are simultaneous (Morgan, 1980) and the absence of $M$. tetracantha is presumably due to the deep marine character of these assemblages. In general, in these Albian assemblages, it is common the presence of species of Diconodinium Eisenack and Cookson 1960 emend. Morgan 1977, Odontochitina (mostly O. costata Alberti 1961) and Canninginopsis denticulata Cookson and Eisenack 1962. In turn, those assemblages from deep marine settings are characterized by high proportions of Impagidinium Stover and Evitt 1978, Pterodinium Eisenack 1958 and chorate cysts like Oligosphaeridium pulcherrimum (Deflandre and Cookson 1955) Davey and Williams 1966b, O. complex, Nematosphaeropsis densiradiata (Cookson and Eisenack 1962b) Stover and Evitt 1968 and

Figure 4. Late Aptian-Albian dinoflagellate cysts from the Upper Río Mayer, Kachaike, Piedra Clavada and "Margas Verdes Formations, onshore Austral Basin. 1, Carpodinium granulatum Cookson and Eisenack emend. Leffingwell and Morgan, ventral view, 1, high focus. 2, cross section PC 05 31/105 N45/4. 3, Prolixosphaeridinium conulum Davey, ventral view, high focus, PC 05 T47 EF T47/4. 4, Dinopterygium tuberculatum (Eisenack and Cookson) Stover and Evitt, antapical view, intermediate focus, MV 35/114 EF. 5, Canninginopsis denticulata Cookson and Eisenack, dorsal view, low focus, MV 23,5/111 EF U53. 6, Diconodinium multispinum (Deflandre and Cookson) Eisenack and Cookson, Oblique right lateral view, low focus, MV 31/105 N46/3. 7, Endoceratium ludbrookiae Cookson and Eisenack emend. Morgan, ventral view, intermediate focus, MV 38/99 H38/2. 8, Litosphaeridium arundum (Eisenack and Cookson) Davey emend. Lucas-Clarke, dorsal view, high focus, Kch 99 35/101 K41/4. 9, Endoceratium turneri (Cookson and Eisenack) Stover and Evitt, dorsal view, low focus, MV 15/114 EF X48. 10, Nematospheropsis densiradiata (Cookson and Eisenack) Stover and Evitt, general view, MV 38/110 S38. 11, Hapsocysta peridictya Eisenack and Cookson emend. Davey, oblique ventral view, high focus, MV 27/108 R50. 12, Hystrichodinium pulchrum Deflandre, left lateral view, high focus, PC 27/113 W50/3. Scale bar $=10 \mu \mathrm{m}$. 


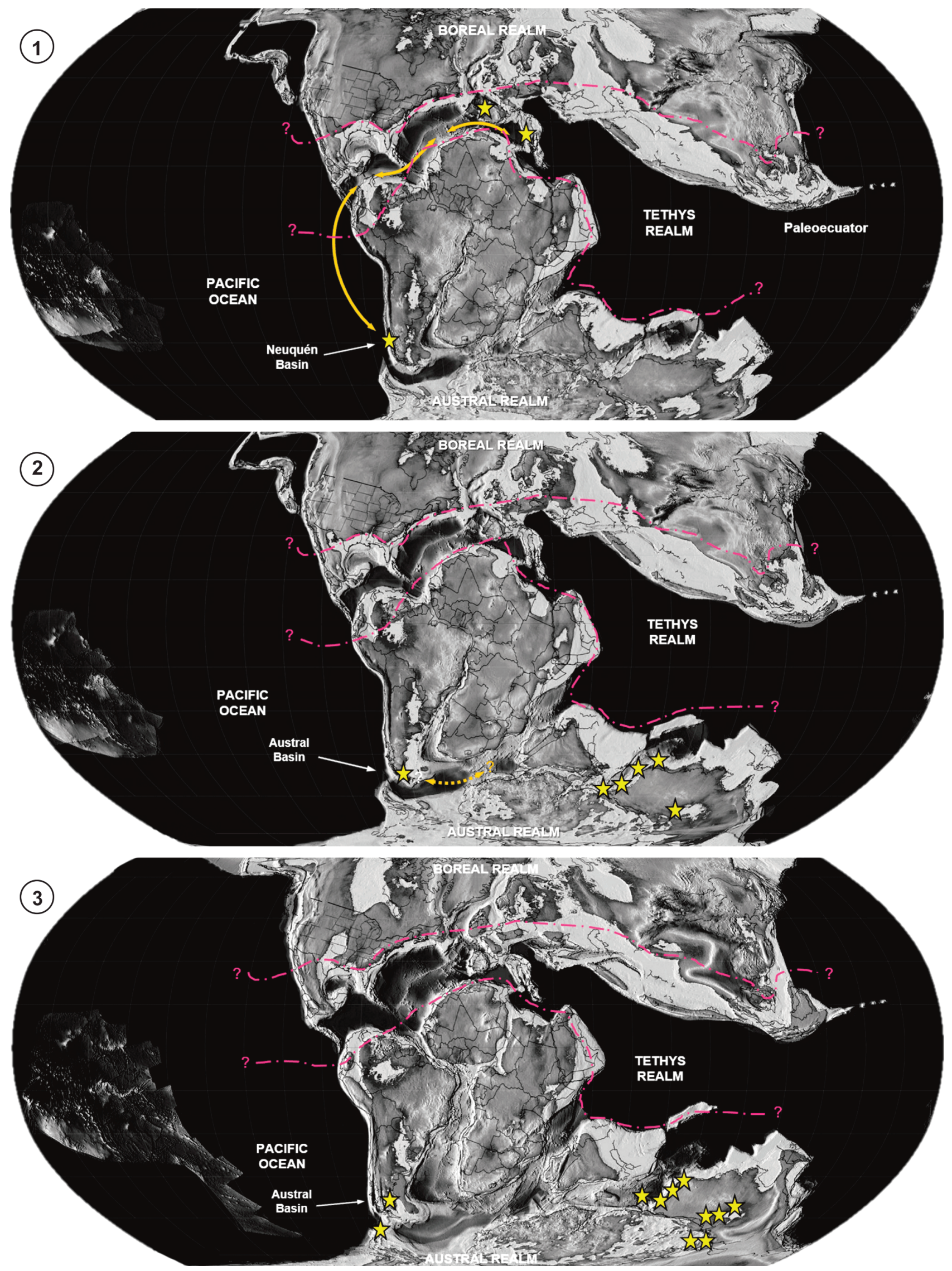


Hapsocysta peridictya, which are typical oceanic taxa. At the upper part of the sequences it is recognized the middle Albian C. denticulata, the late Albian E. ludbroockiae, X. asperatus and the early Cenomanian D. multispinum Zones of Helby et al. (1987) and the equivalent subzones of the $E$. turneri and E. ludbrookiae Zones of Morgan (1980).

Table 1 contains the dinoflagellate cyst species identified in the Austral Basin referenced according to the Fensome and Williams Index; Fensome and Williams (2004).

\section{PALAEOGEOGRAPHIC AND PALAECOLOGIC IMPLICA- TIONS FOR THE AUSTRAL AND NEUQUÉN BASINS}

In general terms, dinoflagellate cyst assemblages from the Pilmatué Member (Peralta, 1997; Volkheimer, 2010; Paolillo et al., 2015) and the Agua de la Mula Member (Guler et al., 2013) of the Agrio Formation, show similarity with the late Valanginian-late Hauterivian assemblages from the Tethyan Realms (e.g., Leereveld 1997a,b; Torricelli 2000; 2001; 2006).

Otherwise, Early Cretaceous dinoflagellate cysts from the southernmost tip of South America, from offshore Austral Basin and southern Patagonia have strong Austral affinities. It is clear that the Australian palynological zonal schemes of Morgan (1980) and Helby (1987) are applicable to Early Cretaceous deposits of the Austral Basin (e.g., Guler et al., 2003; Guler et al., 2015), providing evidence of palaeobiogeographical affinities with the western and central Australia, mainly during Barremian and Aptian times, when the youngest rocks of the Springhill Formation were accumulated (Fig. 5.2). Mid-Cretaceous assemblages from surface and subsurface deposits of the Austral Basin, including Kachaike, Piedra Clavada and Upper Río Mayer; "Margas Verdes" formations (Medina et al., 2008; Guler and
Archangelsky, 2006; Guler, personal observation) compare well with those from well dated sequences of the James Ross Basin, exposed at the north eastern tip of Antarctic Peninsula (Riding and Crame, 2002), which contains one of the thickest and complete Cretaceous sedimentary sequences in the Southern Hemisphere. Also, these Albianearly Cenomanian assemblages are similar to those from Australia (e.g., Morgan, 1980; Helby et al., 1987; Backhouse, 2006) and New Zealand (e.g., Wilson, 1984), reflecting open marine connections among the southernmost part of South America, Antarctic Peninsula, Australia and New Zealand (Fig. 5.3).

Ceratiaceans evolved into a significant number of species through the Early Cretaceous worldwide and they proved to be biostratrigraphically useful in the Boreal and Tethyan Realms (Duxbury, 1977; Leereveld, 1997b; Monteil, 1992) as well as in the Austral region (Helby et al., 1987; Backhouse 1987). The presence of Muderongia staurota, $M$. pariata, M. cf. M. siciliana, and closely related Muderongia morphotypes recorded in the Hauterivian of the Neuquén Basin, denote similarity with the Northern Hemisphere. These species of Muderongia are conspicuous taxa in the Hauterivian Boreal and Tethyan cyst assemblages (e.g., Duxbury, 1977; Leereveld, 1997b; Torricelli, 2000; 2001; 2006) and are absent in the high-latitude Southern Hemisphere basins. Also, typical austral Muderongia species among them Muderongia australis Helby 1987, Muderongia testudinaria Burger 1980 are index taxa for the Australian zonations (Helby et al., 1987; 2004; Backhouse, 1987) and they were not recorded neither in the Northern Hemisphere nor in the Neuquén Basin.

Furthermore, for the Early Cretaceous, assemblages composed by species of Aprobolocysta Duxbury 1977, Ba-

Figure 5. 1, Palaeobiogeographic affinities of the late Valanginian-?early Barremian dinoflagellate cysts of the Neuquén Basin. Palaeogeographic reconstruction of the Early Cretaceous showing the main marine connection between the Neuquén Basin and the Tethyan Realm, Western Europe (Leereveld, 1997; Torricelli, 2000; 2001; 2006). 2, Palaeobiogeographic affinities of the Barremian dinoflagellate cyts of the Austral Basin with the intracratonic areas and marginal basins of Australia (e.g., Helby et al., 1987). Presumable open marine seaways are unknown. 3, Palaeobiogeographic affinities of the Albian dinoflagellate cyts of the onshore Austral Basin with central and the coastal western Australia (Morgan, 1980; Helby et al., 1987; Backhouse, 2006), New Zealand (Wilson 1984) and Peninsula Antarctica (Riding and Crame, 2002). Base maps by Scotese (2013, PALEOMAP). 
tioladinium jaegeri, B. micropodum, Carpodinium granulatum Cookson y Eisenack 1962, emend. Leffingwell y Morgan 1977, Cassiculosphaeridia magna, Dingodinium cerviculum (large forms with relatively thick walls), among others, were associated with relatively cool waters (De Renéville and Raynaud, 1981; Habib and Drugg, 1987; Leereveld, 1995). Based on these criteria, the dinoflagellate cyst assemblages recorded in the Austral Basin characterized by the common presence of these taxa would reflect cool environments. Large thick-walled and coarse ornamented specimens of Dingodiniun cerviculum (Fig 3.1) are common in the Austral Basin assemblages, whereas thin-walled forms (Fig 2.6) were recorded in the Neuquén Basin and other Mediterranean assemblages related to relatively warm environments (Leereveld, 1995, Torricelli 2000, 2001, 2006; Oosting et al., 2006).

Thus, Early Cretaceous dinoflagellate cyst assemblages from southern South America, first from the north of Patagonia, have mediterranean affinities reflecting exchange of taxa between the Mediterranean Sea and the Southeastern Pacific Ocean, and then, with the Neuquén Basin (Fig. 5.1), despite the semi enclosed nature of the basin. The palaeooceanographical connection between the Neuquén Basin and the northwestern and Western Europe during the late Valanginian-late Hauterivian interval is supported by Early Cretaceous echinoids, ammonoids and bivalves, which also proved that water palaeotemperatures would have been properly high to allow immigration of equatorial faunal components (e.g., Aguirre Urreta et al., 2008). Instead, assemblages from the Austral Basin suggest oceanic connection between the southernmost tip of South America and other high-latitudes South Hemisphere sites in Australia, New Zealand and Peninsula Antarctica (Figs. 5.2, 3).

In addition to the global palaeogeography and the palaeooceanographic current context, these palaeobiogeographical affinities are closely related to the geodynamic evolution of the both two basins. During the Berriasianearly Barremian, the Neuquén Basin was connected to the Pacific Ocean (Uliana and Biddle, 1988) through a volcanic arc in the western margin, allowing the incoming of thermophilic taxa from the Tethyan region. On the other hand, the oldest sedimentary fill of the Austral basin (BerriasianBarremian) deposited during the sag phase, represents a long-term (>25 My) transgressive cycle (Robbiano et al., 1996) that is considered contemporary with the initial development of the basin and then, the opening of the Atlantic Ocean (Arbe, 2002). Despite the close palaeogeographical position of both basins, the dinoflagellates cyst assemblages of the Neuquén Basin do not reflect palaeobiogeographic affinities with neither the Austral Basin nor other Southern Hemisphere high latitudes sites, probably due to palaeotemperature differences and/or absence of marine connections.

\section{ACKNOWLEDGEMENTS}

The authors thank the editors and the reviewers E. Pestchevitskaya (Institute of Petroleum Geology and Geophysics, Russia) and Mitsuru Arai (Petrobras, Brazil) for their valuable suggestions that improved considerably the manuscript. We also are grateful to the Agencia Nacional de Promoción Científica y Tecnológica (ANPCyT) and the Universidad de Buenos Aires for their financial support (PICT 1413/13 and UBACYT 20820160200008BA).

\section{REFERENCES}

Aguirre Urreta, M.B., Casadío, S., Cichowolski, M., Lazo, D.G., and Rodríguez, D.L. 2008. Afinidades paleobiogeográficas de los invertebrados cretácicos de la Cuenca Neuquina. Ameghiniana 45: 591-611.

Aguirre Urreta, M.B., and Rawson, P.F. 1997. The ammonite sequence in the Agrio Formation (Lower Cretaceous), Neuquén Basin, Argentina. Geological Magazine 134: 449-458.

Alberti, G. 1961. Zur Kenntnis mesozoischer und alttertiärer Dinoflagellaten und Hystrichosphaerideen von Nord- und Mitteldeutschland sowie einigen anderen europäischen Gebieten. Palaeontographica, Abteilung A 116: 1-58.

Arbe, H.A. 2002. Análisis estratigráfico del Cretácico de la Cuenca Austral. En M.J. Haller (Ed.), Geología y Recursos Naturales de Santa Cruz. Relatorio del $15^{\circ}$ Congreso Geológico Argentino (EI Calafate), p. 103-128.

Arbe, H., and Fernández Bell Fano, F. 2002. Formación Springhill en el área costa afuera. In: M. Schiuma, G. Hinterwimmer, and G. Vergani (Eds.), Rocas Reservorio de las Cuencas Productivas Argentinas p. 75-89. (In CD-Room).

Archangelsky, S., Baldoni, A., Gamerro, J., and Seiler, J. 1984. Palinología estratigráfica del Cretácico de Argentina austral. III. Distribución de las especies y conclusiones. Ameghiniana 21: 15-33.

Backhouse, J. 1987. Microplankton zonation of the Lower Cretaceous Warnbro Group, Perth Basin, Western Australia. In: P.A. Jell (Ed.), Studies in Australian Mesozoic palynology 1, Memoir of the Association of Australasian Palaeontologists 4. Association of Australasian Palaeontologists, Sydney, p. 205-226.

Backhouse, J. 2006. Albian (Lower Cretaceous) Dinoflagellate cyst biostratigraphy of the Lower Gearle Siltstone, Southern Carnarvon Basin, Western Australia. Palynology 30: 43-68.

Baldoni, A.M., Askin, R.A., and Ragona, D. 2001. Palynology of the Lower Cretaceous Kachaike Formation, Santa Cruz Province, Argentina. In: D.K. Goodman, and R.T. Clark (Eds.), Proceedings of the $9^{\circ}$ International Palynological Congress. American Associa- 
tion of Stratigraphic Palynologists Foundation, Houston, p. $191-200$.

Biddle, K., Uliana, M., Mitchum Jr., R., Fitzgerald, M., and Wright, R. 1986. The stratigraphic and structural evolution of central and eastern Magallanes Basin, Southern America. In: P. Allen and P. Homewood (Eds.), Foreland Basins. Blackwell Publishing Ltd., Oxford, p. 41-61.

Bujak, J.P., and Davies, E.H. 1983. Modern and fossil Peridiniineae. American Association of Stratigraphic Palynologists Foundation, Contribution Series 13: 203 p.

Burger, D. 1980. Early Cretaceous (Neocomian) microplankton from the Carpentaria Basin, northern Queensland. Alcheringa 4: 263279.

Clarke, R.F.A., Davey, R.J., Sarjeant, W.A.S., and Verdier, J.P. 1968. A note on the nomenclature of some Upper Cretaceous and Eocene dinoflagellate taxa. Taxon 17: 181-183.

Clarke, R.F.A., and Verdier, J.P. 1967. An investigation of microplankton assemblages from the Chalk of the Isle of Wight, England. Verhandelingen der Koninklijke Nederlandse Akademie van Wetenschappen, Afdeeling Natuurkunde 24: 1-96.

Cookson, I.C., and Eisenack, A. 1958. Microplankton from Australian and New Guinea Upper Mesozoic sediments. Proceedings of the Royal Society of Victoria 70: 19-79.

Cookson, I.C., and Eisenack, A. 1962. Additional microplankton from Australian Cretaceous sediments. Micropaleontology 8: 485-507.

Cornú, P. 1986. [Étude palynologique de la Formation Springhill (Crétace Inférieur d' Argentine Australe). Palynostratigraphie, paléogéographie et paléoécologie. Université de Bordeaux I, Thése 3e cycle, 127 p. Unpublished.].

Davey, R.J. 1969. Non-calcareous microplankton from the Cenomanian of England, northern France and North America, Part I. Bulletin of the British Museum (Natural History), Geology 17: $103-180$.

Davey, R.J. 1970. Non-calcareous microplankton from the Cenomanian of England, northern France and North America, part II. Bulletin of the British Museum (Natural History), Geology 18 : 333-397.

Davey, R.J. 1974. Dinoflagellate cysts from the Barremian of the Speeton Clay, England. Symposium on Stratigraphic Palynology, Birbal Sahni Institute of Palaeobotany, Special Publication 3: 41-75.

Davey, R.J. 1979. Marine Apto-Albian palynomorphs from Holes 400A and 402A, IPOD Leg 48, northern Bay of Biscay. In: L. Montadert, D.G. Roberts, G.A. Auffret, W.D. Bock, P.A. Dupeuble, E.A. Hailwood, W.E. Harrison, H. Kagami, D.N. Lumsden, C.M. Muller, D. Schnitker, R.W. Thompson, T.L. Thompson, P.P. Timofeev, and J.L. Usher (Eds.), Initial Reports of the Deep Sea Drilling Project covering Leg 48 of the cruises of the Drilling Vessel Glomar Challenger, Brest, France to Aberdeen, Scotland, Texas A \& M University, 48: 547-577.

Davey, R.J. 1982. Dinocyst stratigraphy of the latest Jurassic to Early Cretaceous of the Haldager No. 1 borehole, Denmark. Danmarks Geologiske Undersøgelse, Series B 6: 1-57.

Davey, R.J., Downie, C., Sarjeant, W.A.S., and Williams, G.L. 1966. Fossil dinoflagellate cysts attributed to Baltisphaeridium. In: R.J. Davey, C. Downie, W.A.S. Sarjeant, and G.L. Williams (Eds.), Studies on Mesozoic and Cainozoic dinoflagellate cysts. Bulletin of the British Museum (Natural History), Geology, Supplement 3, London, p. 157-175.

Davey, R.J., Downie, C., Sarjeant, W.A.S., and Williams, G.L. 1969. Generic reallocations. In: R.J. Davey, C. Downie, W.A.S. Sarjeant, and G.L. Williams (Eds.), Appendix to "Studies on Mesozoic and Cainozoic dinoflagellate cysts". Bulletin of the British Museum
(Natural History), Geology,Appendix to Supplement 3, London, p. 5-17.

Davey, R.J., and Verdier, J.P. 1973. An investigation of microplankton assemblages from latest Albian (Vraconian) sediments. Revista Española de Micropaleontología 5: 173-212.

Davey, R.J., and Williams, G.L. 1966a. The genera Hystrichosphaera and Achomosphaera. In: R.J. Davey, C. Downie, W.A.S. Sarjeant, and G.L. Williams (Eds.), Studies on Mesozoic and Cainozoic dinoflagellate cysts. Bulletin of the British Museum (Natural History), Geology, Supplement 3, London, p. 28-52.

Davey, R.J., and Williams, G.L. 1966b.V. The genus Hystrichosphaeridium and its allies. In: R.J. Davey, C. Downie, W.A.S. Sarjeant, and G.L. Williams (Eds.), Studies on Mesozoic and Cainozoic dinoflagellate cysts. Bulletin of the British Museum (Natural History), Geology, Supplement 3, London, p. 53-106.

Deflandre, G. 1935. Considérations biologiques sur les microorganisms d'origine planctonique conservés dans les silex de la craie. Bulletin biologique de la France et de la Belgique 69: 213-244.

Deflandre, G. 1937. Microfossiles des silex crétacés. Deuxième partie. Flagellés incertae sedis. Hystrichosphaeridés. Sarcodinés. Organismes divers. Annales de paléontologie 26: 51-103.

Deflandre, G. 1939. Microplancton des mers jurassiques conservé dans les marnes de Villers-sur-Mer (Calvados). Étude liminaire et considérations générales. Travaux de la Station zoologique de Wimereux 13: 147-200.

Deflandre, G. 1947. Sur quelques microorganismes planctoniques des silex Jurassiques. Bulletin de l'Institut Océanographique 921: $1-12$.

Deflandre, G., and Cookson, I.C. 1955. Fossil microplankton from Australian Late Mesozoic and Tertiary sediments. Australian Journal of Marine and Freshwater Research 6: 242-313.

Deflandre, G., and Courteville, H. 1939. Note préliminaire sur les microfossiles des silex crétacés du Cambrésis. Bulletin de la société française de microscopie 8: 95-106.

De Renéville, P., and Raynaud, J.F. 1981. Palynologie du stratotype du Barrémian. Bulletin des Centres de Recherche Exploration Production Elf Aquitaine 5: 1-29.

Dörhöfer, G., and Davies, E.H. 1980. Evolution of archeopyle and tabulation in rhaetogonyaulacinean dinoflagellate cysts. Royal Ontario Museum, Toronto, $91 \mathrm{p}$.

Duxbury, S. 1977. A palynostratigraphy of the Berriasian to Barremian of the Speeton Clay of Speeton, England. Palaeontographica, Abteilung B 160: 17-67.

Duxbury, S. 1983. A study of dinoflagellate cysts and acritarchs from the Lower Greensand (Aptian to Lower Albian) of the Isle of Wight, southern England. Palaeontographica, Abteilung B 186: 18-80.

Ehrenberg, C.G. 1838. Über das Massenverhältniss der jetzt lebenden Kiesel-Infusorien und über ein neues Infusorien-Conglomerat als Polierschiefer von Jastraba in Ungarn. Königlich Akademie der Wissenschaften zu Berlin, Abhandlungen 1: 109-135.

Ehrenberg, C.G. 1843. Über einige Jura-Infusorien Arten des Corallrags bei Krakau. Monatsberichte der Königlichen Preussische Akademie des Wissenschaften zu Berlin p. 61-63.

Eisenack, A. 1958. Mikroplankton aus dem norddeutschen Apt, nebst einigen Bemerkungen über fossile Dinoflagellaten. Neues Jahrbuch für Geologie und Paläontologie, Abhandlungen 106: 383-422.

Eisenack, A. 1972. Kritische Bemerkung zur Gattung Pterospermopsis (Chlorophyta, Prasinophyceae). Critical remarks about Pterospermopsis. Neues Jahrbuch für Geologie und Paläontologie, Monatshefte 10: 596-601. 
Eisenack, A., and Cookson, I.C. 1960. Microplankton from Australian Lower Cretaceous sediments. Proceedings of the Royal Society of Victoria 72: 1-11.

Evitt, W.R. 1963. A discussion and proposals concerning fossil dinoflagellates, hystrichospheres, and acritarchs, I. Proceedings of the National Academy of Sciences of the United States of America 49: $158-164$

Evitt, W.R., Clarke, R.F.A., and Verdier, J.P. 1967. Dinoflagellate studies III. Dinogymnium acuminatum n. gen., n.sp. (Maastrichtian) and other fossils formerly referable to Gymnodinium Stein. Stanford University Publications, Geological Sciences 10: 1-27.

Fensome, R.A., and Williams, G.L. 2004. The Lentin and Williams Index of Fossil Dinoflagellates 2004 Edition. American Association of Stratigraphic Palynologists Contributions Series 42: 909 p.

Firtion, F. 1952. Le Cénomanien inférieur du Nouvion-en-Thiérache: examen micropaléontologique. Annales de la Société géologique du Nord 72: 150-163.

Groeber, P. 1946. Observaciones geológicas a lo largo del meridiano 70. I. Hoja Chos Malal. Revista Sociedad Geológica Argentina 1: 177-208.

Gocht, H. 1957. Mikroplankton aus dem nordwestdeutschen Neokom (Teil I). Paläontologische Zeitschrift 31: 163-185.

Gocht, H. 1970. Dinoflagellaten-Zysten aus dem Bathonium des Erdölfeldes Aldorf (NW-Deutschland). Palaeontographica, Abteilung B 129: 125-165.

Guler, M.V., and Archangelsky, S. 2006. Albian dinoflagellate cysts from the Kachaike Formation, Austral Basin, Southwest Argentina. Revista del Museo Argentino de Ciencias Naturales, nueva serie 8: 179-184.

Guler, M.V., Guerstein, G.R., and Archangelsky, S. 2003. Quistes de dinoflagelados del Cretácico Inferior de la Plataforma Continental Argentina: resultados bioestratigráficos. Revista Museo Argentino de Ciencias Naturales, nueva serie 5: 225-233.

Guler, M.V., Berbach, L., Archangelsky, A., and Archangelsky, S. 2015. Quistes de dinoflagelados y polen asociado del Cretácico Inferior (Formación Springhill) de la cuenca austral, plataforma continental Argentina. Revista Brasileira de Paleontología 18: 307-324.

Guler, M.V., Lazo, D.G., Pazos, P.J., Borel, CM., Ottone, E.G., Tyson, R.V., and Aguirre Urreta, M.B. 2013. Palynofacies analysis and palynology of the Agua de la Mula Member (Agrio Formation) in a sequence stratigraphy framework, Lower Cretaceous, Neuquén Basin, Argentina. Cretaceous Research 41: 65-81.

Habib, D., and Drugg, W.S. 1987. Palynology of Sites 603 and 605, Leg 93, Deep Sea Drilling Project. In: J.E. Van Hinte, S.W. Wise, B.N.M. Biart, J. Mitchener Covington, D.A. Dunn, J.A. Haggerty, M.W. Johns, P.A. Meyers, M.R. Moullade, J.P. Muza, J.G. Ogg, M. Okamura, M. Sarti, and U. von Rad (Eds.), Initial Reports of the Deep Sea Drilling Project covering Leg 93 of the cruises of the Drilling Vessel Glomar Challenger, Norfolk, Virginia, to Norfolk, Virginia 92: 751-775.

Harding, I.C. 1990. A dinocyst calibration of the European boreal Barremian. Palaeontographica Abteilung B 218: 1-76.

Helby, R. 1987. Muderongia and related dinoflagellates of the latest Jurassic to Early Cretaceous of Australasia. In: P.A. Jell (Ed.), Studies in Australian Mesozoic palynology. Memoir of the Association of Australasian Palaeontologist 4: 297-336.

Helby, R., Morgan, R., and Partridge, A.D. 1987. A palynological zonation of the Australian Mesozoic. In: P.A. Jell (Ed.), Studies in Australian Mesozoic palynology. Memoir of the Assocation of Australasian Palaeontologists 4: 1-94.

Helby, R., Morgan, R., and Partridge, A.D. 2004. Updated Jurassic Early
Cretaceous dinocyst zonation NWS Australia. Geoscience Australia Publication. World Wide Web: http: //www.ga.gov.au/metadatagateway/metadata/record/gcat_61127

Helenes, J. 1984. Morphological analysis of Mesozoic-Cenozoic Cribroperidinium (Dinophyceae), and taxonomic implications. Palynology 8: 107-137.

Hernández, M.P., Concheyro, A., Lazo, D., Rodríguez, D., Aguirre Urreta, M.B., and Ottone, E.G. 2005. Asociaciones palinológicas, nanofósiles calcáreos e invertebrados del Miembro Agua de la Mula, Formación Agrio, en su localidad tipo, provincia del Neuquén. In: E. Llambías, R. de Barrio, P. González, and P. Leal (Eds.), $16^{\circ}$ Congreso Geológico Argentino (La Plata), Actas versión CD-Room, p. 1-8.

Jansonius, J. 1986. Re-examination of Mesozoic Canadian dinoflagellate cysts published by S.A.J. Pocock $(1962,1972)$. Palynology 10: 201-223.

Khowaja-Ateequzzaman, Garg, R., and Jain, K.P. 1990. Observations on archaeopyle type in fossil dinoflagellate cyst species Dingodinium cerviculum Cookson and Eisenack 1958. The Palaeobotanist 37: 267-277.

Leereveld, H. 1995. Dinoflagellate cysts from the Lower Cretaceous Río Argos succession (SE Spain). Laboratory of Palaeobotany and Palinology Contribution Series 2: 1-176.

Leereveld, H. 1997a. Hauterivian-Barremian (Lower Cretaceous) dinoflagellate cyst stratigraphy of the western Mediterranean. Cretaceous Research 18: 421-456.

Leereveld, H. 1997b. Upper Tithonian-Valanginian (Upper JurassicLower Cretaceous) dinoflagellate cyst stratigraphy of the western Mediterranean. Cretaceous Research 18: 385-420.

Leffingwell, H.A., and Morgan, R.P. 1977. Restudy and comparison of the dinoflagellate cyst genus Carpodinium to that of Prionodinium n. gen. Journal of Paleontology 51: 288-302.

Legarreta, L., and Gulisano, C. 1989. Análisis estratigráfico secuencial de la Cuenca Neuquina (Triásico superior-Terciario inferior). In: G.A. Chebli, and L.A. Spalletti (Eds.), Cuencas sedimentarias argentinas, Serie Correlación Geológica 6: 221-243.

Legarreta, L., and Uliana, M.A. 1991. Jurassic-Cretaceous Marine Oscillations and Geometry of Back Arc Basin, Central Argentina Andes. In: D.I.M. McDonad (Ed.), Sedimentation, Tectonics and Eustasy: Sea-Level Changes at Active Margins. Blackwell Publishing Ltd., Oxford, p. 429-450.

Legarreta, L., Gulisano, C., and Uliana, M. 1993. Las secuencias sedimentarias jurásico-cretácicas. In: V. Ramos (Ed.), Geología y Recursos Naturales de Mendoza. Relatorio del $12^{\circ}$ Congreso Geológico Argentinoy $2^{\circ}$ Congreso de Hidrocarburos (Mendoza), p. 87-114.

Lentin, J.K., and Vozzhennikova, T.F. 1990. Fossil dinoflagellates from the Jurassic, Cretaceous and Paleogene deposits of the USSR - a re-study. American Association of Stratigraphic Palynologists, Contributions Series, 23: $221 \mathrm{p}$.

Lucas-Clark, J. 1984. Morphology of species of Litosphaeridium (Cretaceous, Dinophyceae). Palynology 8: 165-193.

Mantell, G.A. 1854. The Medals of Creation: or, First Lessons in Geology and the Study of Organic Remains. Henry G. Bohn, London, U.K, $930 \mathrm{p}$.

Medina, F.S., Archangelsky, S., Guler, V., Archangelsky, A., and Cárdenas, O. 2008. Estudio bioestratigráfico integrado del perfil La Horqueta (límite Aptiano-Albiano), Lago Cardiel, Patagonia, Argentina. Revista del Museo Argentino de Ciencias Naturales 10: $273-289$.

Millioud, M.E. 1969. Dinoflagellates and acritarchs from some western European Lower Cretaceous type localities. In: P. Brönnimann, 
and H.H. Renz (Eds.), $1^{\circ}$ International Conference on Planktonic Microfossils (Geneva), p. 420-434.

Monteil, E. 1991a. Revision of the dinoflagellate cyst genus Cometodinium Deflandre \& Courteville, 1939, emend. Enantiomorphy in a fossil dinoflagellate cyst population. Bulletin des Centres de recherches exploration-production Elf-Aquitaine 15: 439-459.

Monteil, E. 1991b. Morphology and systematics of the ceratioid group: a new morphographic approach. Revision and emendation of the genus Muderongia Cookson and Eisenack 1958. Bulletin des Centres de recherches exploration-production Elf-Aquitaine 15: 461-505.

Monteil, E. 1992. Quelques nouvelles espèces-index de kystes de dinoflagellés (Tithonique-Valanginien) du sud-est de la France et de l'ouest de la Suisse. Revue de Paléobiologie 11: 273-297.

Morgan, R. 1975. Some Early Cretaceous organic-walled microplankton from the Great Australian Basin, Australia. Journal and Proceedings of the Royal Society of New South Wales 108: 157-167.

Morgan, R. 1980. Palynostratigraphy of the Australian early and middle Cretaceous. Geological Survey of New South Wales, Palaeontology Memoir 18: 181-153.

Newton, E.T. 1875. On "Tasmanite" and Australian "White Coal". Geological Magazine 2: 337-342.

Nøhr-Hansen, H. 1993. Dinoflagellate cyst stratigraphy of the Barremian to Albian, Lower Cretaceous, North-East Greenland. Bulletin Grønlands Geologiske Undersøgelse 166: 1-171.

Oosting, A.M., Leereveld, H., Dickens, G.R., Henderson, R.A., and Brinkhuis, H. 2006. Correlation of Barremian-Aptian (mid-Cretaceous) dinoflagellate cyst assemblages between the Tethyan and Austral realms. Cretaceous Research 27: 792-813.

Ottone, E.G., and Aguirre Urreta, M.B. 2000. Palinomorfos cretácicos de la Formación Springhill en Estancia El Salitral, Patagonia Austral. Ameghiniana 37: 379-382.

Ottone, E.G., and Pérez Loinaze, V.S. 2002. A new dinoflagellate from the Lower Cretaceous of Argentina. Ameghiniana 39: 117-120.

Ottone, E.G., Guler, M.V., Borel, C.M., Lazo, D.G., and Aguirre Urreta, M.B. 2008. Avances en la palinología del Miembro Agua de la Mula de la Formación Agrio, Cretácico Temprano de Cuenca Neuquina. $17^{\circ}$ Congreso Geológico Argentino (San Salvador de Jujuy), Actas 2: 787-788.

Palamarczuk, S., Archangelsky, A., Barreda, V., Gamerro, J.C., and Archangelsky, S. 2000a. Datos palinológicos en dos perforaciones de la plataforma continental argentina (Valanginiano-Cenomaniano) cuenca Austral. $11^{\circ}$ Simposio Argentino de Paleobotánica y Palinología (Tucumán), Resúmenes p. 83

Palamarczuk, S., Gamerro, J.C., and Barreda, V. 2000b. Estudio palinológico en el pozo Chiton MFJ8 x-1, plataforma continental argentina, Cuenca Austral. $11^{\circ}$ Simposio Argentino de Paleobotánica y Palinología (Tucumán), Resúmenes p. 84.

Paolillo, M.A., Guler, M.V., Ottone G.E., Pazos, J., Lazo D.G., and Aguirre-Urreta, M.B. 2015. Quistes de dinoflagelados del Miembro Pilmatué (Formación Agrio), Cretácico inferior de Cuenca Neuquina, Argentina. Ameghiniana, Suplemento-Resúmenes 52: 69R-70R.

Peralta, P. 1997. [Dinoflagelados de la Formación Agrio (Cretácico Inferior) del Cerro Negro y Cerro Mesa de Covunco, Cuenca Neuquina. Tesis Doctoral, Facultad de Ciencias Exactas, Físicas y Naturales, Universidad Nacional de Córdoba, 213 p. Unpublished.].

Peralta, P., and Volkheimer, W. 1997. Paleoenvironmental aspects of the Lower Cretaceous Agrio formation, inferred by dinocyst assemblages, Neuquén Basin, Argentina. Neues Jahrbuch für Geologie und Palaeontologie 204: 3-15.

Peralta, P., and Volkheimer, W. 2000. Early Cretaceous sea level variations and changes in dinocyst assemblages and organic matter components in the Neuquén Basin, western Argentina. Neues Jahrbuch für Geologie und Palaeontologie 10: 613-631.

Pöthe de Baldis, E.D., and Ramos, V. 1983. Dinoflagelados del Aptiano inferior de Río Fósiles, Lago San Martín, Provincia de Santa Cruz, Argentina. Revista Española de Micropaleontología 15: 427-446.

Pöthe de Baldis, E.D., and Ramos, V. 1988. Microplancton adicional del Aptiano de Río Fósiles Lago San Martin, Provincia de Santa Cruz, Argentina y su correlación con Australia. $4^{\circ}$ Congreso Argentino de Paleontología y Bioestratigrafía, (Mendoza), Actas 3: 23-40.

Prössl, K.F. 1990. Dinoflagellaten der Kreide-Unter-Hauterive bis Ober-Turon-im niedersächsischen Becken. Stratigraphie und Fazies in der Kernbohrung Konrad 101 sowie einiger anderer Bohrungen inNordwestdeutschland. Palaeontographica Abteilung B 218: 93-191.

Quattrocchio, M.E., and Sarjeant, W.A.S. 1992. Dinoflagellate cysts and acritarchs from the Middle and Upper Jurassic of the Neuquén Basin, Argentina. Revista Española de Micropaleontología 24: 67-118.

Quattrocchio, M., and Volkheimer, W. 1983. Datos palinológicos de la Formación Picún Leufú (Jurásico superior) en su localidad tipo, provincia del Neuquén. Revista de la Asociación Geológica Argentina 38: 34-48.

Quattrocchio, M., and Volkheimer, W. 1985. Estudio palinológico del Berriasiano en la localidad de Mallín Quemado, provincia del Neuquén. Ameghiniana 21: 187-204.

Quattrocchio, M., and Volkheimer, W. 1990. Jurassic and Lower Cretaceous dinocysts from Argentina: Their biostratigraphic significance. Review of Palaeobotany and Palynology 65: 319-330.

Quattrocchio, M.E., Martínez, M.A., Carpinelli Pavisich, A., and Volkheimer, W. 2006. Early Cretaceous palynostratigraphy, paIynofacies and palaeoenvironments of well sections in northeastern Tierra del Fuego. Cretaceous Research 27: 584-602.

Riding, J.B., and Crame, J.A. 2002. Aptian to Coniacian (Early-Late Cretaceous) palynostratigraphy of the Gustav Group, James Ross Basin, Antarctica. Cretaceous Research 23: 739-760.

Riding, J.B., Poulsen, N.E., and Bailey, D.A. 2001. A taxonomic study of the dinoflagellate cyst Muderongia simplex Alberti 1961 and related species. Palynology 24: 21-35.

Robbiano, J.A., Arbe, H.A., and Gangui, A. 1996. Cuenca Austral marina. In: V. Ramos, and M. Turic (Eds.), Geología y Recursos Naturales de la Plataforma Continental Argentina. Relatorio del $13^{\circ}$ Congreso Geológico Argentino y $3^{\circ}$ Congreso de Exploración de Hidrocarburos (Capital Federal), p. 323-34.

Sarjeant, W.A.S. 1959. Microplankton from the Cornbrash of Yorkshire. Geological Magazine 96: 329-346.

Sarjeant, W.A.S. 1966. Dinoflagellate cysts with Gonyaulax-type tabulation. In: R.J. Davey, C. Downie, W.A.S. Sarjeant, and G.L. Williams (Eds.), Studies on Mesozoic and Cainozoic dinoflagellate cysts. Bulletin of the British Museum (Natural History) Geology, Supplement 3: 107-156.

Sarjeant, W.A.S. 1968. Microplankton from the Upper Callovian and Lower Oxfordian of Normandy. Revue de micropaléontologie 10: $221-242$.

Sarjeant, W.A.S., and Stover, L.E. 1978. Cyclonephelium and Tenua: a problem in dinoflagellate cyst taxonomy. Grana 17: 47-54.

Sarjeant, W.A.S. 1980. Restudy of a 19th-Century dinoflagellate cyst holotype from the Polish Upper Jurassic. Acta Paleontologica Polonica 25: 279-285.

Sarjeant, W.A. 1985. The German Aptian dinoflagellate cysts of Eise- 
nack (1958): a restudy. Review of palaeobotany and palynology 45: 47-106

Schwarz, E., Veiga, G.D., Spalletti, L.A., and Massaferro, J.L. 2011. The transgressive infill of an inherited-valley system: the Springhill Formation (Lower Cretaceous) in southern Austral Basin, Argentina. Marine and Petroleum Geology 28: 1218-1241.

Scotese, C.R. 2013. PALEOMAP Paleo Atlas for ArcGIS, volume 2, Cretaceous, PALEOMAP Project, Evanston, I. World Wide Web: http://www.scotese.com

Srivastava, S.K.1984. Barremian dinoflagellate cysts from southeastern France. Cahiers de micropaléontologie 2: 1-90.

Stover, L.E., and Evitt, W.R. 1978. Analyses of pre-Pleistocene organic-walled dinoflagellates. Stanford University Publications, Geological Sciences 15: 300 p.

Stover, L.E., and Helby, R. 1987. Early Cretaceous dinoflagellates from the Vinck-1 well, offshore Western Australia. In: P.A. Jell (Ed.), Studies in Australian Mesozoic palynology; Memoir of the Association of Australasian Palaeontologists 4: 227-260.

Tasch, P., McClure, K., and Oftedahl, O. 1964. Biostratigraphy and taxonomy of a hystrichosphere - dinoflagellate assemblage from the Cretaceous of Kansas. Micropaleontology 10: 189-206.

Torricelli, S. 1997. Two new Early Cretaceous dinoflagellate cyst species from the Monte Soro Flysch (Sicily, Italy). Review of Palaeobotany and Palynology 96: 339-345.

Torricelli, S. 2000. Lower Cretaceous dinoflagellate cyst and acritarch stratigraphy of the Cismon APTICORE (Southern Alps, Italy). Review of Palaeobotany and Palynology 108: 213-266.

Torricelli, S. 2001. Dinoflagellate cyst stratigraphy of the Lower Cretaceous Monte Soro Flysch in Sicily (S Italy). Revista Italiana di Paleontologia e Stratigrafia 107: 79-105.

Torricelli, S. 2006. Dinoflagellate cyst stratigraphy of the Scisti a Fucoidi Formation (early Cretaceous) from Piobbico, central Italy: calibrated events for the Albian of the Tethyan Realm. Rivista Italiana di Paleontologia e Stratigrafia 112: 95-111.

Uliana, M.A., and Biddle, K.T. 1988. Mesozoic-Cenozoic paleogeographic and geodynamic evolution of southern South America. Revista Brasilera de geociencias 18: 172-190.

Uliana, M.A., and Legarreta, L. 1993. Hydrocarbons habitat in a triassic-to-cretaceous sub-andean setting: Neuquén Basin, Argentina. Journal of Petroleum Geology 16: 397-420.
Volkheimer, W. 1980. Microfloras del Jurásico Superior y Cretácico Inferior de América Latina. $2^{\circ}$ Congreso Argentino de Paleontolo-

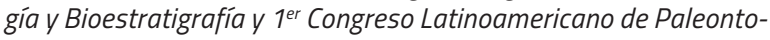
logía (Buenos Aires), Actas 5: 121-136.

Volkheimer, W. 2010. Early Cretaceous dinoflagellate cysts from the southern border of the Neuquén Basin, Estancia Santa Elena locality, Argentina. Revista del Museo Argentino de Ciencias Naturales 12: 233-253.

Volkheimer, W., and Sarjeant, W.A.S. 1993. Systematophora rosenfeldii n. sp., a Lower Cretaceous dinoflagellate from the Neuquén Basin, central western Argentina. Neues Jahrbuch für Geologie und Paläontologie 4: 246-256.

Wetzel, O. 1933. Die in organischer Substanz erhaltenen Mikrofossilien des baltischen Kreide-Feuersteins mit einem sediment-petrographischen und stratigraphischen Anhang. Palaeontographica, Abteilung A 77: 141-186.

White, H.H. 1842. On fossil Xanthidia. Microscopical Journal 11: 3540.

Williams, G.L., Ascoli, P., Barss, M.S., Bujak, J.P., Davies, E.H., Fensome, R.A., and Williamson, M.A. 1990. Chapter 3: Biostratigraphy and related studies. In: M.J. Keen, and G.L. Williams, (Eds.), Geology of the Continental Margin of Eastern Canada. Geological Survey of Canada 2: 87-137.

Wilson, G.J. 1984. New Zealand late Jurassic to Eocene dinoflagellate biostratigraphy - a summary. Newsletters on Stratigraphy 13: 104-117.

Doi: 10.5710/PEAPA.18.10.2016.116

Recibido: 3 de mayo de 2016

Aceptado: 18 de octubre de 2016 